\title{
De Marcelo Caetano ao Portugal democrático as relações internacionais da transição
}

\author{
ANTÓNIO JosÉ TELO \\ Academia Militar Portuguesa \\ From Marcelo Caetano to Portuguese Democracy. The
International Relations during the Transition
}

RESUMEN

Este artículo, fundamentalmente referido al período de transición y consolidación democrática que sigue al 25 de Abril de

1974, pretende encuadrar el período marcelista en un contexto más amplio, examinando los rasgos de continuidad que el aparente corte de la "revolución» mantiene. En ese sentido, el eje central de este estudio son las alteraciones que la «revolucão dos cravos» aporta a la relación de Portugal con el mundo. Pienso que queda demostrado que muchas de las mudanzas que en este terreno se producen después del "25 de Abril», ya habían sido preparadas en la etapa de Marcelo Caetano, mediante pasos parciales, que los condicionamientos políticos del momento impedían llegar a su conclusión lógica.

PALABRAS CLAVE: Marcelo Caetano. Política exterior. Revolución y transición democrática

\section{ABSTRACT}

This article, essentially related to the transition and consolidation democratic period following the 25th April 1974, attempts to situate the marcelist government in a wider context, looking into the continuity of traits beyond the apparent revolutionary rupture. So, the core of this study is the changes that the "revolução dos cravos" brough to the Portuguese relationship with the world. As a conclusion, I would like to prove that many of the changes that took place after the 25th April uprising had been partially prepared under marcelist period, even thought the restricted political condition of that time prevented a thorough achievement.

KEYWORDS:

Marcelo Caetano. Portuguese Foreign Policy. Revolution and Transition to Democracy 


\section{INTRODUÇÃO}

As linhas que se seguem obedecem a duas condicionantes que não quero deixar de indicar à partida. A primeira é que vou tratar das relações internacionais de Portugal e não meramente da sua actividade diplomática ou da política externa. Neste período de transição entre o salazarismo e o Portugal democrático a diplomacia apaga-se e perde importância, porque o seu corpo profissional fica paralisado nos momentos chave e porque se multiplicam os canais de contacto com o exterior. Estes passam pela actividade dos Governos, mas, ao seu lado e por vezes com mais importância, temos uma ampla panóplia de acções externas de indivíduos e instituições muito diversas. Estas abarcam, por exemplo, a Igreja, os partidos, os sindicatos, os grupos económicos, as associações de agricultores ou os serviços de informações externos.

Em segundo lugar, gostaria de salientar que estamos perante um processo complexo e multifacetado, difícil de abarcar e acompanhar. Os agentes multiplicam-se e quase todos têm projectos e estratégias próprias, numa matriz de estímulos contraditórios. O que é mais, os projectos e estratégias são muitas vezes bizarros e exóticos, só compreensíveis tendo em conta a mentalidade muito própria e original das personagens envolvidas que, sem estarem preparados na sua maioria, são arrastados no turbilhão da mudança rápida.

É igualmente notório que as estratégias e conceitos mudam muito rapidamente. Mesmo em relação às instituições mais responsáveis - como, por exemplo, o Governo dos EUA ou da URSS - é difícil atribuir-lhes uma política num dado momento. A situação normal, é que no seio de cada instituição existem sensibilidades e políticas contraditórias e em conflito, resultando a acção concreta do seu choque, sem imposição clara de uma ou outra. Estamos perante um processo onde o interno e o externo se misturam, sendo muito difícil dizer o que pertence a um ou a outro.

\section{A CONTINUIDADE E A MUDANÇA}

Aparentemente em 1974 ocorre um corte radical com o passado, uma «revolução" que mudou tudo à sua passagem numa espécie de furacão. Na realidade, muita coisa mudou, a começar nas grandes opções estratégicas da política externa portuguesa. É mesmo possível falar num «regresso das caravelas», que, passados cinco séculos, retornam aos portos que as viram partir.

No entanto, para além desta aparência, que pode ser apresentada com frases mais ou menos dramáticas, temos de reconhecer a permanência de factores de continuidade de longo prazo. A opção europeia, por exemplo, era já uma realidade operante e efectiva desde o começo dos anos sessenta, quando a CEE se transformou na principal referência comercial, económica, financeira, tecnológica e hu- 
mana do país. O milhão e meio de portugueses que emigrou em 1960-1974 foi esmagadoramente (mais de um milhão) para a França e a Alemanha, ou seja, para os dois principais países da CEE e não para a EFTA ou para África. A Europa do Tratado de Roma, em resumo, era a grande referência das relações externas de Portugal já no período de Marcelo Caetano, embora a política externa tivesse a África no centro do seu discurso até 1974. Neste sentido não houve realmente um corte radical com o passado. O que se deu foi um ajustamente há muito adiado: a política externa oficial passou a coincidir com o que já era a opção real.

Vejamos um outro exemplo, não menos significativo: o caso da NATO. Desde 1961 que Portugal estava de costas viradas para a organização. A participação nas actividades regulares da NATO foi em permanente queda entre 1961 e 1966, para depois sofrer uma ligeira recuperação com a formação do IBERLANT e o regresso da Armada aos exercícios anuais de treino e à STANAVFORLANT. Nos anos de Marcelo Caetano houve claramente um estreitar de laços com os EUA e a NATO, numa espécie de preparação do que iria acontecer depois de 1975.

Mesmo assim, o enquadramento do país na NATO em 1974 era uma pálida imagem da relação existente no final dos anos 50 , quando essa instituição era a grande referência externa da política de defesa. Neste sentido, o corte com a secular tradição Attãntica portuguesa não se deu em 1974, mas sim em 1961, quando a política de defesa nacional foi revista para passar a ter a manutenção das colónias como objectivo central. Com Marcelo Caetano, é notório a preparação do regresso à NATO como enquadramento central da política de defesa nacional, o que só se concretiza depois do 25 de Abril. Estamos neste campo, não propriamente em presença de uma «revolução», mas sim de um retomar da secular tradição de enquadramento da defesa nacional principalmente no contexto do Atlântico e dos poderes que o dominam. A revolução, em resumo, serviu para regressar à tradição e não para cortar com o passado.

Citemos ainda um terceiro exemplo: o sistema político. A secular tradição portuguesa era a de acompanhar os sistemas políticos prevalecentes na Europa Ocidental, com pequenas diferenças. Por vezes, o país era mesmo dos mais avançados em termos do sistema político, no sentido de que se antecipava de dezenas de anos a uma evolução que acabava por ser seguida pela maior parte da Europa Ocidental. Foi o caso, por exemplo, da Constituição de 1822 (uma das mais avançadas do seu tempo, inspirada na Constituição da Cadiz) ou da República de 1910 (somente a segunda República da Europa nesta altura). Esta tradição só se quebra com a 2. ${ }^{a}$ Guerra Mundial, quando na esmagadora maioria da Europa Ocidental se implanta a democracia representativa pluralista, enquanto a Península se torna numa ilha dos anos 30 , onde se mantém regimes ditatoriais. 0 25 de Abril também neste campo representou um regresso à tradição portuguesa, com a difícil e conturbada transição para um regime semelhante aos existentes na Europa Ocidental, o que era um passo prévio essencial para se participar no movimento de integração europeia. 
Foi ainda nos anos de Marcelo Caetano que, em 1972, se assina o acordo de comércio com a CEE, um documento essencial para o futuro. O acordo de 1972 prevê um regime de comércio especial para Portugal, com uma amplo período de adaptação da economia antes da abertura total. As suas disposições são a base da relação com a CEE em todo o longo período de pré-adesão, que decorre até 1985. O acordo de 1972 era o reconhecimento da importância da CEE para Portugal mas, ao mesmo tempo, era o reconhecimento que Marcelo Caetano não podia dar o que seria o passo lógico de pedir a adesão.

Verificamos com estes exemplos dois pontos que são essências para compreender o que se vai passar. Em primeiro lugar, em muitos casos a chamada revolução de Abril mais não faz que apressar o regresso de Portugal à sua secular tradição em termos das relações externas, cortando com o período anormal que começou em 1960. Em segundo lugar, em quase todos os casos os anos de Marcelo Caetano foram uma transição, uma espécie de preparação da inflexão futura antes desta ocorrer.

\section{O ENQUADRAMENTO DA GUERRA FRIA}

A transição portuguesa para a democracia é um marco importante da passagem da segunda para a terceira fase do sistema internacional bipolar, ou da Guerra Fria. Este forma-se depois de 1945 e dura cerca de meio século. Conhece três fases distintas: 1945-1961; 1961-1973/74; 1973/74-1990/91. Não as vamos descrever, mas é necessário mencionar os pontos mais importantes da $3 .{ }^{a}$ fase que condicionam a evolução portuguesa.

Uma das características do começo dos anos 70, é o fim do longo período de ouro do desenvolvimento económico que vinha do pós-guerra e que foi simplesmente o mais rápido e sustentado período de crescimento rápido da economia mundial de que há memória histórica e estatística. De repente, as principais economias do planeta passam de taxas de crescimento anuais da ordem dos 5 a $14 \%$ ou mais, para uns meros 1 a 3\%, quando não para uma evolução negativa. O principal marco desta mudança é a chamada «crise de petróleo» de 1973, que tem fortes repercussões em Portugal, implicando nomeadamente a morte de alguns dos grandes projectos do Marcelismo, como Sines ou a metalurgia.

Na terceira fase da guerra fria que começa em 1973/74 a capacidade dos dois pólos do sistema (EUA e URSS) de exercerem uma hegemonia nas respectivas esferas está muito atenuada. Por um lado, estas esferas já estão longe de abarcar quase todo o planeta como acontecia em 1945/61, ficando de fora zonas como a China, a Índia e importantes partes da África e Europa. Ainda mais importante é o facto do peso relativo das chamadas «superpotências» ser muito menor que em 1945, o que é especialmente patente no bloco ocidental. Há ainda uma hegemonia bipolar, ao contrário do que aconteceria depois de 1990, mas ambas enfraquecidas. 
Os EUA em especial eram uma sombra do grande poder que se formou na parte final da 2. ${ }^{\text {a }}$ Guerra, tanto em termos da sua capacidade de canalizar recursos significativos para uma acção externa como da vontade de manter um empenhamento activo semelhante ao do passado. Depois da traumatizante derrota do Vietname, que se transformaria a curto prazo no abandono e queda do regime do Sul, os EUA não concebem uma repetição do processo. As instituições do Governo Federal e a opinião pública vigiam com especial atenção tudo que se assemelhe a um empenhamento activo em zonas onde não estejam em causa interesses vitais do país, de modo a evitar uma «escalada automática» como a que conduziu à guerra do Vietname. A maior parte dos responsáveis americanos considera que uma das «lições» a tirar é que, ou se intervém depressa, em força e de forma eficiente, ou mais vale ficar quieto e deixar os acontecimentos seguirem o seu curso, só se justificando a primeira opção quando há interesses vitais em jogo. Esta «lição» do Vietname seria testada com o caso de Angola e acabaria por contribuir para o recuo americano, do mesmo modo que seria um dos principais motivos do não empenhamento directo de Washington em Portugal.

Internamente os EUA são uma sociedade traumatizada pela primeira derrota séria da sua História, pela divisão interna que ela provocou e pela contestação dos valores tradicionais. A acrescentar a tudo isto, têm um executivo ferido de morte. A presidência Nixon entra em Abril de 1974 na fase final da crise Watergate, que culminaria passados quatro meses com a demissão do Presidente, um caso único desde a independência das 13 colónias. Os traumas pós- Vietname e a fraqueza da presidência iriam condicionar de forma importante a política dos EUA para Portugal, Angola, Moçambique ou Timor. A atitude americana seria muito diferente se 025 de Abril se tivesse dado anos antes.

Um dos efeitos internos da situação, era a anormal acumulação de poder no secretário de estado Henry Kissinger, uma das poucas figuras prestigiadas da administração Nixon, que definia e aplicava com grande independência a política externa americana. Kissinger não só dirigia nesta fase o Departamento de Estado, como coordenava a diversificada e poderosa comunidade dos serviços de informações, uma concentração de poder muito anormal. Nixon pouco interferia na política externa, numa altura em que a sua grande preocupação era o fantasma do «impeachement» e o futuro presidente Ford nunca revelou um especial conhecimento ou empenho pelo caso português.

As dificuldades e a mudança de política americana eram entendidas pela URSS como uma janela de oportunidade. A administração Brejnev enfrenta o futuro com confiança, depois de anos de um desenvolvimento económico ainda rápido, resolvidos já os problemas mais urgentes na Europa Oriental através da intervenção armada na Checoslováquia e após ter finalmente alcançado a paridade nuclear estratégica com os EUA, alvo central dos esforços russos desde a explosão da primeira bomba atómica em Hiroshima (1945). A paridade nuclear entre as super-

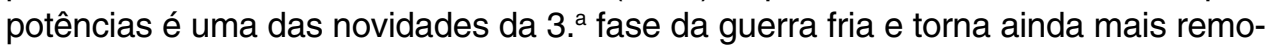


ta a possibilidade de um conflito aberto entre elas, o que significa que nenhuma pensa ameaçar directamente os interesses vitais da outra. A retirada dos EUA da Indochina e a evidente falta de empenho da administração americana para se envolver em novas aventuras no $3 .^{\circ}$ mundo é entendida por Moscovo como uma janela de oportunidade única. Um dos motivos porque a URSS sente que não pode deixar de tentar ocupar o vazio de poder no $3 .^{\circ}$ mundo é que receia que a China o faça.

É uma mudança de fundo da anterior política soviética cautelosa em relação a África e à Ásia. O primeiro campo da sua aplicação seria o vazio deixado pelo colapso do império português, especialmente o caso de Angola, muito cedo mergulhada na guerra civil. Seguir-se-ia a Etiópia e o Afeganistão, bem como aventuras noutros continentes, nomeadamente na Nicarágua. Esta mudança está associada a outra, da qual é inseparável, embora pareçam contraditórias.

A URSS tem consciência, como já referimos, que os EUA não podem ser desafiados em zonas onde consideram que os seus interesses vitais estão em causa, como o caso da guerra entre Israel e os Árabes de 1973 provou, quando o empenhamento americano foi forte, directo e imediato, apesar das dificuldades internas da administração. Significa isto que o Governo soviético adopta uma atitude de forte empenhamento em Angola, mas de recuo perante a perspectiva de criar um confronto directo com os EUA na Europa e, muito em especial, num país da NATO, como Portugal. Paralelamente, a URSS canaliza os escassos recursos financeiros próprios para as «aventuras» no $3 .^{\circ}$ mundo. O caso de Cuba tinha provado que não bastava levar um partido amigo a conquistar o poder; era necessário depois financiar o novo regime perante a reacção adversa de economias mais poderosas, o que implicava um custo significativo e permanente em divisas, ponto onde a URSS era especialmente fraca. Os múltiplos empenhamentos no $3 .^{\circ}$ mundo que começam em 1975 implicam que deixa de haver recursos para financiar a modernização das economias da Europa Oriental, o que leva Moscovo a aceitar uma abertura aos capitais e à iniciativa empresarial ocidental.

É este facto que leva à definição da chamada «ostpolitik» da Alemanha Ocidental, a abertura a leste em termos políticos e financeiros, encarada com fortes reservas e grande dose de incompreensão por Washington. A «ostpolitik» teria grande importância para o futuro, pois foi um dos elementos que mais contribuiu para a queda do muro de Berlim a médio prazo, com a expansão da influência ocidental em amplos sectores das sociedades do Leste. A mudança da política soviética no começo da $3 .^{a}$ fase, em resumo, é coerente, mas tem aplicações muito diferentes conforme se trata de Angola - onde o endurecimento do empenhamento directo é evidente - ou da Europa Ocidental, onde a URSS aposta no desanuviamento, no fortalecimento da CEE, na busca da colaboração e no incentivar dos investimentos e transferências de tecnologia, aspectos vitais para as economias da Europa do Leste.

Outra das características da terceira fase da guerra fria que mais importância tem para Portugal, é o fortalecimento da CEE e a mudança de política que se dá 
nas suas principais capitais, muito em especial em Bona. A CEE tinha acabado de se alargar ao norte da Europa (adesão da Inglaterra, Dinamarca e Irlanda) e surgia como a grande aposta da Europa, onde se estava a construir um novo tipo de realidade política, numa arquitectura adaptada às sociedades pós-industriais. Bruxelas ainda estava longe de ter uma política externa ou de defesa coerente, mas era evidente o seu empenhamento no processo de democratização do sul do continente. $\mathrm{O} 25$ de Abril surge igualmente numa altura em que uma anormal percentagem de estados europeus é governada por gabinetes ligados à Internacional Socialista (RFA, Inglaterra, países escandinavos, parcialmente a Itália). A RFA apostava claramente na ostpolitik de abertura ao leste e de fortalecimento da sua esfera de influência própria em termos da Europa Central (realidade geopolítica em construção nesta altura).

Nesse sentido, a RFA era muito sensível à evolução da Península, não só porque mantinha especiais laços com Portugal desde longa data ${ }^{1} \mathrm{e}$ tinha fortes interesses na sua economia, mas porque receava que um conflito entre as superpotências à volta de Portugal viesse destruir o clima de desanuviamento e entendimento que era para ela essencial na Europa. Recordemos nomeadamente que a revolução portuguesa coincide com a preparação da conferência sobre segurança e cooperação europeias em Helsínquia, onde tanto a URSS como a RFA apostavam fortemente, com reservas evidentes dos EUA. Não é assim para admirar que a decisão do governo e das instituições da RFA tenha sido desde muito cedo a de se empenharem no processo português no sentido de ajudar à vitória das forças democráticas, de modo a despoletar um dos mais perigosos focos de conflito potencial na Europa, que poderia pôr em causa todo o clima de onde saiu a «ostpolitik» e a OSCE. Também a Inglaterra adopta uma política semelhante, com a diferença que os recursos que pode investir no caso português são muito inferiores aos alemães.

A revolução portuguesa, em resumo, é condicionada pela mudança de fundo que se dá na Europa Ocidental com a passagem para a 3. ${ }^{a}$ fase da guerra fria e, muito em especial, por dois factores que se revelariam dos mais importantes: a maturidade da CEE depois da adesão da Inglaterra, que se afirma como a grande aposta de futuro da Europa Ocidental; a mudança de política de fundo da RFA, com o seu empenhamento na Ostpolitik.

Deixei para o final o que é, numa opinião pessoal, a característica da $3 .^{a}$ fase da guerra fria que maior significado tem para o caso português: o nascimento do que Samuel Huntington ${ }^{2}$ chamou a terceira vaga das revoluções democráticas, o mais importante movimento isolado do final do século xx. É um movimento que começa justamente por Portugal e que rapidamente se alarga ao sul da Europa (à

\footnotetext{
1 Desde os anos 60 que a RFA era o principal parceiro de Portugal em termos do comércio e dos financiamentos externos.

${ }^{2}$ Samuel Huntington, The Third Wave: Democratisation in the late Twentieh Century, Norman, University of Oklahma Press, 1991.
} 
Grécia, em Julho de 1974, e à Espanha, em 1975). Tem tal importância, que será ele a acabar com o muro de Berlim e a própria URSS quando, passados 15 anos, os seus efeitos atingem em pleno a Europa Oriental. A transição surge em Portugal, tal como no sul da Europa, como um efeito directo do período longo de desenvolvimento acelerado do pós-guerra, quando a sociedade portuguesa passa de rural a pós-industrial (sem nunca ser industrial), quando as cidades crescem e quando a classe média se consolida e desenvolve, mudando de hábitos e atitudes sob pressão nomeadamente da juventude estudantil e da abertura ao mundo da sociedade da informação. É um processo que tem como motor directo o «milagre europeu» e, em particular, a locomotiva da CEE (apesar de Portugal estar ligado à EFTA). Ele implica uma imensa abertura da sociedade portuguesa ao exterior, que passa nomeadamente pelo envio de mais de 1,5 milhões de emigrantes para a Europa desde 1962 (qualquer coisa como 40\% da população activa nacional), pela invasão regular de perto de 4 milhões de turistas por ano (um crescimento de 15 vezes em 12 anos), pelo desenvolvimento da educação e pela chegada dos modernos meios de comunicação de massas. São efeitos irresistíveis de um processo de crescimento que não depende dos Governos e se integra na globalização. Portugal foi o primeiro caso de revolução democrática pelo simples motivo que os 13 anos de guerra colonial funcionaram como um imenso acelerador do processo. Foi a guerra que criou as Forças Armadas politizadas que puseram fim ao regime e, ao mesmo tempo, bloqueou os esforços de liberalização ensaiados por Marcelo Caetano desde 1969.

Podemos dizer, em resumo, que Portugal foi um caso pioneiro da mudança para a $3{ }^{\text {a }}$ fase da guerra fria e do desencadear do mais importante movimento político do final do século xx. Os acontecimentos nacionais só se podem entender à luz desta mudança de fase do sistema internacional, muito em especial no que diz respeito à forma como ela condiciona as estratégias e políticas dos EUA, da URSS, da CEE e da RFA, tal como indicamos de forma muito resumida.

\section{A DESCOLONIZAÇÃO COMO EIXO CENTRAL DA RELAÇÃO COM O MUNDO (ABRIL A SETEMBRO DE 1974)}

A primeira fase das relações externas de Portugal depois do 25 de Abril terá a descolonização como tema central ${ }^{3}$. É uma fase que começa com o 25 de Abril e é difícil dar-lhe um limite claro para fim. Podemos dizer que ela termina algures entre a publicação da lei 7/74 (27 de Julho de 1974), que abre caminho à descolonização efectiva com o reconhecimento formal do princípio da autodeterminação, e os acordos de Alvor, a 15 de Janeiro de 1975, onde se determina o processo de in-

3 Se considerar-mos o processo como um todo, o tema central e o eixo condutor dos acontecimentos entre o 25 de Abril e o 25 de Novembro é a questão do tipo de regime a implantar em Portugal, mas se considerar-mos somente o aspecto das relações internacionais, então a tónica da primeira fase tem de ser colocada na descolonização, assunto intimamente ligado ao primeiro. 
dependência da última grande colónia portuguesa, depois da assinatura de acordos semelhantes com a Guiné e Moçambique. Talvez uma boa data para pôr fim a esta fase seja 30 de Setembro de 1974, quando o Presidente Spínola se demite.

Os anos finais de Marcelo Caetano, como muito bem refere Hipólito de la Torre, são uma espécie de antecâmara da descolonização, pois são dados passos nesse sentido de forma discreta ou mesmo secreta, sem que fosse possível assumir que se procurava efectivamente um caminho para colocar fim à guerra. No caso da Guiné, o embaixador Vila-Boas relatou as negociações secretas que teve com o PAIGC em Londres, em 1973 e começos de 1974, para tentar encontrar um acordo de cessar-fogo. No caso de Moçambique, Marcelo Caetano incentiva as diligências de Jorge Jardim a partir do Malawi, que conduzem a uma proposta para acabar com a guerra elaborada em Lusaka e apresentada em Lisboa poucos dias antes do 25 de Abril - a posição oficial de Marcelo Caetano foi a de dizer a Jorge Jardim que tinha «ido longe de mais», sem apoiar oficialmente o chamado «plano de Lusaka». No caso de Angola, Marcelo Caetano chega a pensar numa declaração unilateral de independência branca, semelhante à da Rodésia, de modo a criar um governo em Luanda que poderia em seguida negociar uma solução com os movimentos de libertação, sem estar preso às condicionantes do governo de Lisboa. Havia, em resumo, uma série de diligências promovidas secretamente por Marcelo Caetano que apontavam para o facto de ele estar consciente da necessidade de acabar a curto prazo com as guerras, mas sem que nenhuma se tivesse concretizado quando do 25 de Abril.

O 25 de Abril desfaz em poucas horas o aparelho central do Estado e cria uma situação de poderes paralelos, com atitudes e políticas diferentes. Surgem múltiplas instituições que não tem campos de acção claros e todas com ambições em termos de política externa: o Presidente da República Spínola, que insiste em assumir pessoalmente a responsabilidade da política para com a guerra de África, a Junta de Salvação Nacional, a comissão coordenadora do MFA e o Governo Provisório. Isto para já não mencionar os partidos, muito em especial o $\mathrm{PCP}$, que implementa uma política própria para África através de canais autónomos e independentes.

É preciso recordar que em Abril de 1974 não há partidos políticos fortes. O que mais se assemelha a isso é o velho PCP, com uns poucos milhares de quadros e simpatizantes disciplinados ${ }^{4}$, que é um dos partidos comunistas mais tradicionais e pouco evoluídos da Europa Ocidental. O PS, recentemente fundado, é classificado pela embaixada americana em Lisboa como «os amigos do Dr. Soares» ${ }^{5}$ e à sua direita é o vazio. A ausência de um aparelho político que cubra o leque de

4 É difícil dar um número exacto. Não andaremos muito longe da verdade com os limites de 3000 a 5000.

5 Mário Soares referiu que quando do 25 de Abril o PS deveria ter à volta de 1000 militantes, com uma organização vaga e difusa onde os laços pessoais eram importantes. Ver Soares, Ditadura e Revolução, entrevista de Maria João Avillez, Lisboa, 1996, p. 321. 
opções normal nas democracias ocidentais é um resultado directo da falhada liberalização de Marcelo Caetano. A JSN e o presidente Spínola nos primeiros tempos incentivam a formação de partidos à direita do $\mathrm{PS}$, tendo dirigido convites formais nesse sentido a várias personalidades, como Sá Carneiro, Diogo Freitas do Amaral ${ }^{6}$ e até ao general Kaulza de Arriaga.

Esta situação particular tem três consequências com efeitos externos importantes. A primeira, é que as principais forças políticas já criadas ou em formação pouco se preocupam com a política externa nos primeiros tempos, pois a sua prioridade vai para a consolidação da organização própria num ambiente de vazio de poder. A segunda, é que se desenvolvem diplomacias paralelas com os fins mais dispares: umas tem preocupações nacionais e nesta fase centram-se no problema da solução das guerras de África; outras, visam somente defender os interesses das instituições que as promovem e tem como principal objectivo a angariação de fundos e apoios para a sua consolidação e crescimento ${ }^{7}$. A terceira, é a paralisia das vias tradicionais da política externa, especialmente do corpo de diplomatas profissional que é surpreendido pelo 25 de Abril, tal como acontece com muitos outros sectores da sociedade portuguesa.

\subsection{O corpo diplomático}

Vale a pena desenvolver um pouco este último ponto. O 1. a Governo Provisório só se forma oficialmente em meados de Maio. Mário Soares é a opção natural para Ministro dos Negócios Estrangeiros ${ }^{8}$, tendo em conta que é o dirigente incontestado do único partido democrático português existente quando do 25 de Abril e que o general Spínola o pretende afastar de posições de maior relevo. Mário Soares, a pedido de Spínola, percorre as principais capitais da Europa ainda antes da nomeação (desde 2 de Maio) para conquistar as boas vontades para o novo regime. Os seus contactos pessoais revelam-se preciosos, nomeadamente na Inglaterra. A escolha de Mário Soares levanta, porém, algumas reservas no Presidente Spínola, cioso de manter o controlo sobre o processo de descolonização, de se afirmar como o pivot do diálogo com os poderes ocidentais e de ganhar tempo para as forças mais à direita do espectro político se organizarem ${ }^{9}$.

${ }^{6}$ Diogo Freitas do Amaral, O Antigo Regime e a Revolução, Lisboa, Livraria Bertrand, 1995.

7 Este movimento é muito amplo e crescerá com o tempo. Podemos dizer que não houve nenhuma instituição portuguesa importante que não tenha recorrido nesta altura a generosos financiamentos externos, desde a Igreja, aos partidos, sindicatos, associações laborais, associações patronais, federações de cooperativas, etc. E claro que umas beneficiaram mais que outras. Um relatório da CIA de começos de 1975, para dar só um exemplo, calculava o financiamento do PCP proveniente da URSS, RDA e países de Leste em cerca de 1 milhão de dólares por mês.

${ }^{8}$ Será o Ministro dos Negócios Estrangeiros dos 3 primeiros Governos Provisórios, entre 15 de Maio de 1974 e 26 de Março de 1975 . Melo Antunes dirige a diplomacia portuguesa no $4 .{ }^{\circ}$ e $6 .^{\circ}$ Governos Provisórios, enquanto no 5. ${ }^{a}$ Governo o seu responsável será Mário Ruivo.

${ }^{9}$ Spínola afirmou posteriormente ao embaixador João Hall Themido que colocou Sá Carneiro como ministro sem pasta no Governo Provisório para que este pudesse «controlar» melhor a actividade externa 
Mário Soares enfrenta um primeiro problema prático de difícil solução quando é colocado à frente do MNE. Havia fortes pressões no sentido de fazer o saneamento do corpo de diplomatas ${ }^{10}$, especialmente por parte do PCP e mesmo de certos sectores do PS ${ }^{11}$. Imediatamente a seguir ao 25 de Abril, que seja do meu conhecimento, só um embaixador colocou o lugar à disposição ${ }^{12}$ e nenhum diplomata de carreira apresentou a demissão ${ }^{13}$. Pelo contrário muitos apressaram-se a mandar telegramas de felicitações às novas autoridades e alguns houve mesmo que não hesitaram em adoptar «sinais exteriores» de radicalismo político, onde se incluía a participação em manifestações. A maioria, no entanto, limitou-se a aguardar os acontecimentos com uma mal disfarçada ansiedade.

Mário Soares resiste às pressões para um saneamento político em termos do afastamento de profissionais da carreira o que, tanto quanto me foi possível apurar, não ocorreu. A sua preocupação nesse campo, como referiu em discursos então feitos aos funcionários do Ministério, foi a de deixar o campo livre para quem se quisesse demitir por não concordar com a nova política, mas recusar um saneamento. As pressões vão-se manter por muitos meses à medida que os governos e os responsáveis mudam, tendo passado por várias fases. O período pior correspondeu ao $5 .^{\circ}$ Governo Provisório, como seria de esperar. Chegou-se a formar uma "comissão de saneamento", mas que nunca se levou muito a sério.

Mário Soares, sem um conhecimento directo e extenso do corpo diplomático quando foi nomeado ministro, sem confiar na sua generalidade em termos políticos, mas com urgentes e prementes tarefas externas, optou pela chamada «táctica da ilha». Na prática, criou à sua volta um pequeno staff de confiança (onde se destacava o chefe do gabinete Vitor Cunha Rego, o diplomata Mário Sá Machado e Bernardino Gomes) e partiu de imediato para uma volta pelas capitais mais importantes para Portugal, deixando a pesada máquina do Ministério entregue ao secretário geral ${ }^{14}$, embaixador Calvet de Magalhães, reduzida à gestão dos assuntos

de Mário Soares. O grande erro político de Spínola, numa opinião pessoal, foi o de não ter entendido a necessidade de uma aliança com o PS nas circunstâncias e ter confundido a pressão que este fazia para a presença de comunistas no Governo com um entendimento geral entre os dois partidos.

10 Segundo o último Anuário Diplomático anterior ao 25 de Abril, referente a 1 de Julho de 1973, dos 13 embaixadores em funções só $2(15 \%)$ eram «políticos» e estavam em capitais pouco importantes (Pinto Coelho, em Buenos Aires, e José Hermano Saraiva, em Brasília). O corpo diplomático de carreira era então formado por um quadro de 11 embaixadores, 18 ministros de $1 .{ }^{a}, 28$ ministros de $2 .^{a}, 36$ conselheiros, 40 primeiros secretários, 48 segundos secretários e 50 terceiros secretários, num total de 231 elementos.

11 A noção de um corpo de diplomatas profissional que se limita a executar a política governamental sem necessariamente se identificar com ela consolida-se principalmente depois do 25 de Abril. Antes, Franco Nogueira tinha desenvolvido esforços no sentido da crescente profissionalização do corpo de diplomatas, o que é natural num ministro que vem da carreira, mas foram dados passos atrás no período de Rui Patrício.

12 O Prof. José Hermano Saraiva, embaixador no Brasil.

${ }_{13}$ Segundo informações do Embaixador Calvet de Magalhães, então secretário geral do Ministério, houve mais tarde um conselheiro que apresentou a demissão por rejeitar as políticas do $5 .^{\circ}$ Governo. A demissão foi aceite, mas o diplomata seria posteriormente readmitido.

${ }_{14} \mathrm{O}$ Embaixador Calvet de Magalhães mantém as funções de Secretário Geral (que já exercia) por algum tempo depois do 25 de Abril, antes de ser colocado na Santa Sé. 
correntes. Em certo sentido, podemos dizer que até o Ministro dos Negócios Estrangeiros criou uma diplomacia paralela, pois no essencial não usou a máquina do Ministério nos primeiros tempos para executar a política própria.

Os embaixadores em funções no 25 de Abril foram chamados a Lisboa para consultas. Alguns seriam mudados para posto menos importantes ou retidos na disponibilidade, em períodos mais ou menos longos de inactividade, enquanto não lhes eram atribuídas novas funções. Só dois embaixadores se mantiveram nos postos (o de Berna e o de Washington). Merece menção especial o caso do Embaixador João Hall Themido, que permaneceu em Washington dez anos ${ }^{15}$. Foi uma forma de procurar tranquilizar os EUA, para lhes dar a ideia que os factores de continuidade eram fortes em termos externos.

A abertura ao mundo que se dá depois do 25 de Abril, cria novas missões no exterior e abre caminho à entrada de um amplo lote de embaixadores "políticos». Abriu igualmente à carreira às mulheres, até aí excluídas. Em $1979{ }^{16}$, o corpo diplomático tinha sido alargado de 231 para 290 elementos nos últimos 6 anos. O aumento era especialmente notório nos embaixadores (os 13 de 1973 passaram para 33 em 1979) e, enquanto antes do 25 de Abril só $15 \%$ eram de nomeação política (2 em 13), em 1979 esta percentagem passou para 36\% (12 em 33). É igualmente de realçar que $63 \%$ dos embaixadores existentes em 1979 foram promovidos ou nomeados depois do 25 de Abril ${ }^{17}$.

\subsection{A descolonização}

A descolonização é o eixo central deste período inicial em termos internos e externos. Ninguém duvida, aliás, que a evolução interna irá depender sobretudo da solução das guerras de África, a causa isolada principal do 25 de Abril. Spínola reserva o problema formalmente para si, mas, na realidade, ele será afectado pela conjugação de pelo menos 4 políticas principais e algumas secundárias: a de Spínola, Mário Soares, Melo Antunes e do PCP, sendo que esta última foi a mais bem sucedida de todas, especialmente em Angola.

A orientação inicial do Presidente da República é a de sair rapidamente da Guiné, onde se reconhece que a situação militar é complicada, mas com a preocupação de a separar de Cabo Verde, onde não há luta armada. Em Angola e Moçambique Spínola tentará a manutenção de algum tipo de laços com Portugal dentro de uma grande autonomia, embora tal não tenha de corresponder necessariamente à solução gaullista da Federação tal como era defendida no famoso liv-

15 Entre 1971 e 1981. Ver Dez Anos em Washington, João Hall Themido, Lisboa, D. Quixote, 1995.

16 A publicação do Anuário Diplomático, que nos serve de fonte, foi interrompida em 1974 e só recomeçou em 1979.

17 Dos 13 embaixadores de 1973, passados 6 anos, 2 que eram de nomeação política cessaram funções, 1 faleceu, 4 estavam aposentados ou na disponibilidade e só 6 continuavam no activo. 
ro Portugal e o Futuro. A ideia do referendo, porém, era importante e nela o Presidente da República fará finca pé, até porque era uma forma de afastar as atenções da luta armada para a luta eleitoral e de permitir a organização de grupos moderados em África ${ }^{18}$. Era uma política que teria fortes hipóteses de ser bem sucedida se aplicada no começo dos anos 60 e que, mesmo em 1969, poderia ser tentada com algumas possibilidades de êxito, mas que estava condenada ao fracasso em $1974{ }^{19}$.

O avanço da luta armada na Guiné e em Moçambique eram suficientes para condenar qualquer ideia de federação - a Guiné era já reconhecida por mais países que os que mantinham relações diplomáticas com Portugal - enquanto a mudança da situação internacional geral Ihe tirava qualquer hipótese em Angola. $O$ que era mais, uma tal política para ter algumas hipóteses, precisava de contar com um dispositivo militar crível e com uma direcção política unida e firme enquanto as negociações durassem e tal era impossível depois do 25 de Abril. A disciplina militar dissolveu-se, a cadeia hierárquica de comando ficou paralisada, a vontade de combater das unidades no terreno desceu na vertical e começou em Portugal um forte movimento contra a continuação dos embarques que produziu efeitos quase imediatos.

Todo o processo se dá num clima de pulverização do poder central do Estado e multiplicação de poderes paralelos, com uma forte pressão de um movimento popular espontâneo que ninguém verdadeiramente controla. A descolonização real está recheado de pormenores caricatos bem reveladores. Damos somente um exemplo: os representantes dos movimentos de libertação nas capitais europeias chegavam a manter contactos com uma diferença de poucas horas com Mário Soares, com enviados de Spínola e com dirigentes do PCP, que desconheciam a sua existência mútua e que lhes diziam obviamente coisas diferentes.

No essencial, porém, até Setembro de 1974 a responsabilidade principal da política de descolonização cabe ao general Spínola, que a assume e defende. É de Belém que partem as directivas e instruções concretas para a descolonização. Spínola, por exemplo, terá sempre a preocupação de fazer acompanhar Mário Soares de um representante da sua confiança que vigie o respeito pela sua política na mesa das negociações - no caso das primeiras negociações com a Frelimo a escolha recai em Otelo Saraiva de Carvalho. Será o próprio Presidente da República que, em poucas semanas se convence da impossibilidade de aplicar o seu projecto

18 A rápida mudança das políticas de Spínola para a descolonização faz com que alguns autores o considerem uma personalidade caricata e cheguem a dizer que não tinha política para África. Não penso assim. O general Spínola levava a descolonização a peito e pensava que era o nó central do problema político português, embora alimentasse inicialmente a esperança de concretizar uma política amplamente irrealista, que ele próprio alteraria a curto prazo.

${ }_{19}$ É curioso constatar que no começo dos anos 60 o próprio Marcelo Caetano, em documento não publicado e de circulação interna, defendia uma solução de ampla autonomia que podia chegar à federação para o problema africano. Nunca teve a coragem ou a oportunidade de a tentar aplicar depois de 1969 , quando a sua concretização seria já muito duvidosa. 
político inicial e recua passo a passo. Normalmente o recuo é atribuído às pressões do MFA ou de outras forças políticas nacionais e até mesmo aos efeitos perversos das diplomacias paralelas, mas, segundo penso, o factor fundamental que levou à mudança da posição do Presidente foi a tomada de consciência gradual da realidade envolvente.

Na prática, o dilema de base não tinha solução: os movimentos de libertação recusavam-se a negociar um cessar fogo sem a aceitação do princípio da autodeterminação, que entendiam como a independência dada a Governos da sua exclusiva responsabilidade. A única excepção era a UNITA. O motivo era simples mas inapelável: retirando o caso do PAIGC, os movimentos de libertação eram demasiado fracos e estavam demasiado divididos para poderem aceitar um referendo com livre organização de outros grupos e faltavam-lhes todos os elementos para se lançarem numa actividade eleitoral dentro das regras do jogo das democracias ocidentais, sem tradições nas sociedades africanas. A solução que Spínola queria impor, em resumo, era inaceitável e ele pura e simplesmente não tinha força para obrigar o outro lado a ceder.

Enquanto o impasse prosseguia, no terreno o dispositivo militar português desfazia-se de forma inapelável, as pressões externas das mais diversas origens (ONU ${ }^{20}$, OUA ${ }^{21}$, EUA ${ }^{22}$, CEE, Senegal, Zaire, etc...) iam todas no sentido de aconselhar o reconhecimento da independência imediata. Os apoios externos à guerrilha cresciam diariamente, num processo paralelo ao desfazer dos vectores de acção nacionais. O tempo, em resumo, corria contra a política de Spínola. O Presidente da República parece ter-se convencido a partir de certa altura que a continuação do impasse só beneficiava a infiltração do PC nas Forças Armadas e a radicalização de todo o processo. Escassos três meses depois do 25 de Abril, Spínola reconhece a derrota da sua política inicial ao promulgar a lei $7 / 74$, que abre o caminho para as negociações da independência com os movimentos de libertação, com exclusão de outras forças.

Aparentemente, por detrás deste recuo está a preocupação do Presidente da República com o crescimento da força e implantação do PCP e o desejo de se concentrar na organização de um movimento interno que se transforme numa alternativa tanto ao PC como ao PS, o que seria difícil enquanto o impasse da descolonização e a continuação da guerra alimentasse a agitação mais radical. Há igualmente, segundo tudo indica, ainda a esperança de tratar Angola como um caso diferente, mas esta não tarda a morrer. Mais uma vez as razões de fundo são

20 A ONU logo a 9 de Maio de 1974 faz um apelo à Junta de Salvação Nacional para que aceite a autodeterminação e inicie negociações imediatas com os movimentos de libertação nessa base.

21 A OUA ainda a 16 de Junho de 1974 recomenda o isolamento de Portugal enquanto o novo regime não aceitar a independência das colónias.

22 O Presidente Nixon confirmou pessoalmente ao general Spínola no encontro entre os dois nos Açores (a 19 de Junho de 1974) que os EUA eram favoráveis à autodeterminação das colónias portuguesas, tal como afirmavam desde 1961. 
inapeláveis: para que Portugal pudesse determinar as condições do processo de independência precisava de uma capacidade de projectar e exercer poder de forma coordenada, o que passava pela afirmação de uma direcção política forte, por um dispositivo militar no terreno crível, pelo investimento de recursos económicos e financeiros e pela aptidão de canalizar apoios externos. Nenhuma dessas condições existia, nem podia ser recuperada a curto prazo. A única à qual se podia recorrer seria a canalização de apoios externos para acompanhamento e controlo do processo das independências, mas as alternativas reais não eram muitas: ou os EUA, que não mostravam disponibilidade para cumprir esse papel, ou o Brasil, que tinha disponibilidade mas não era aceite pelos movimentos africanos e não estava próximo do regime português para merecer a sua confiança.

Spínola reconhece a impossibilidade de manter o impasse logo em Julho e assume com realismo a responsabilidade dos principais recuos até Setembro de 1974 , ou seja, na fase mais importante do processo. Quando o general se afasta de Belém já estão assinados os acordos com a Guiné e Moçambique e, sobretudo, estão tomadas no essencial por ele as duas opções de fundo que tudo condicionam: aceitar a independência imediata; negociar só com os movimentos que fizeram a luta armada.

\subsection{Moderação e reconhecimento externo}

O novo Ministro dos Negócios Estrangeiros quando toma posse em meados de Maio tem essencialmente duas preocupações centrais, para além da descolonização. A primeira, é consolidar o reconhecimento externo do novo regime e dar garantias aos principais aliados e amigos de que os compromissos seriam respeitados. Mário Soares tem a preocupação, ainda antes de ser nomeado ministro, de usar a sua rede de contactos pessoais nas capitais europeias para tranquilizar os respectivos governos quanto às intenções do novo regime. Este seria rapidamente reconhecido pelos principais estados. O primeiro seria o Brasil (a 28 de Abril), seguido da África do Sul (29 de Abril) e dos EUA, RFA, Espanha e Formosa (a 30 de Abril) ${ }^{23}$. A segunda preocupação, intimamente ligada à primeira, era a de dissuadir qualquer intervenção externa directa em Portugal. O maior perigo partia da Espanha na Europa e dos regimes de Pretória e Salisbúria em África.

A Espanha era a principal ameaça externa potencial, pois era sabido que os acordos de defesa existentes desde 1939 e reforçados no pós-guerra previam uma ajuda militar mútua em caso de um golpe interno que degenerasse em desordens

${ }^{23}$ É de notar que neste grupo inicial estavam as mais importantes referências da política externa do Estado Novo, tanto na Europa, como na África e América. As razões de estado sobrepuseram-se facilmente às simpatias ideológicas e levaram países como a Espanha e a África do Sul a serem dos primeiros a reconhecer o novo regime. Nesta altura vigorava em quase todas as capitais a teoria que o reconhecimento de um Governo que dominasse claramente o território era automático, mediante a mera continuação das relações diplomáticas e troca de notas. 
e guerra civil. A vitória rápida do 25 de Abril retirava esse pretexto e Madrid tem consciência da falta de apoio externo para uma qualquer ingerência evidente nos assuntos portugueses. Ainda não é possível consultar os principais documentos sobre este assunto, mas todos os sintomas apontam para o facto da decisão espanhola de não intervir ter sido tomada rapidamente e sem opiniões contrárias ${ }^{24}$. Simplesmente, a possibilidade de uma intervenção armada directa era somente o caso extremo de um amplo leque.

Durante o século $\mathrm{xx}$, a Espanha tinha já adoptado várias vezes a política de apoiar a oposição portuguesa e de permitir que ela actuasse a partir do seu território e mesmo que organizasse incursões armadas - como, por exemplo, as incursões de Paiva Couceiro ou os planos de actuação dos republicanos exilados a partir da Espanha no começo dos anos 30. Portugal adopta desde o primeiro momento uma política de dissuadir uma tal atitude. Tanto Mário Soares ${ }^{25}$ como futuramente Melo Antunes indicam por diversas vezes aos representantes espanhóis que Lisboa não apoia a oposição ao regime de Franco na organização de acções a partir de Portugal e pretende a manutenção de relações cordiais, dando a entender que se espera uma contrapartida idêntica. A política espanhola neste campo passa por várias fases, mas tudo indica que ela foi marcada por grande contenção e moderação enquanto o general Spínola se manteve em Belém.

A outra fonte de preocupação em termos de uma intervenção externa são as intenções dos regimes brancos da África Austral, principalmente em Moçambique. Tanto o general Spínola como Mário Soares, por vários canais, procuram dissuadir uma acção radical de Pretória. Logo em começos de Maio, por exemplo, o general Spínola proíbe Jorge Jardim de sair de Portugal e recusa-se a considerar o chamado "programa de Lusaka", um projecto para acabar com a guerra em Moçambique que tinha fortes possibilidades de conduzir à divisão da colónias em duas ou mais partes. Mário Soares, por seu lado, pede a James Calaghan em Londres que modere os desejos de intervenção da África do Sul e alarga o pedido em relação ao Malawi, com diligências junto dos americanos ${ }^{26}$.

Também o caso do Brasil levanta algumas dúvidas, pois era um país com fortes laços com o Estado Novo, que não escondia as suas ambições na África portuguesa. Brasília será a primeira capital a reconhecer a nova situação e as re-

24 Joseph Sánchez Cervelló (A Revolução Portuguesa, Lisboa, 1993, p. 346) refere que vários ministros se mostraram preocupados com as repercussões em Espanha dos acontecimentos no Conselho de 26 de Abril, mas nem sequer se discutiu a eventualidade de uma intervenção.

25 Mário Soares fala pouco depois do 25 de Abril com o embaixador espanhol em Londres (Manuel Fraga Iribarne), com quem contacta através de Fernando Morán. Será ela o primeiro responsável espanhol a garantir que não se pensa em qualquer intervenção. António Poch, Embaixador da Espanha em Lisboa, confirma esta ideia. Mesmo assim, Mário Soares refere que nas digressões iniciais pelas capitais da Europa democrática, não se esquecia de pedir que fizessem sentir a Madrid que uma qualquer intervenção em Portugal seria mal recebida. O primeiro contacto directo entre Mário Soares (já MNE) e o seu congénere espanhol, só se dá a 27 de Junho de 1974, numa escala em Madrid do avião que, muito simbolicamente, vai de Bruxelas para Lisboa.

26 Entrevista de Maria João Avillez, op. cit., p. 345. 
lações de estado revelam-se cordiais, embora se tenha registado uma reaç̧ão negativa de amplos sectores da emigração portuguesa e uma reacção positiva de muitos sectores da oposição à ditadura. O Brasil alimenta a intenção de interferir na descolonização portuguesa e oferece-se para medianeiro. Lisboa nunca dará seguimento a estas sugestões, o que não só se insere dentro de uma linha tradicional da política externa portuguesa, mas é feito sobretudo porque o lado africano não aceita a ideia de uma mediação do Brasil.

São ainda de registar preocupações dos responsáveis portugueses com a reacção das comunidades de imigrantes em todo o mundo. Era importante que as remessas não fossem paralisadas ou substancialmente reduzidas, o que implicava conquistar a confiança das comunidades de emigrantes. São tomadas medidas imediatas sobretudo em relação aos países da CEE e aos EUA, onde a questão se complicava pela presença de uma forte componente Açoreana entre os emigrantes. É nesta função junto dos emigrantes que a acção do corpo diplomático tradicional é mais importante depois do 25 de Abril. São dadas instruções específicas para uma campanha de relações públicas junto dos grupos e associações dos emigrantes e para a presença mais activa dos representantes do Estado português nas suas festas e reuniões.

\subsection{A abertura ao mundo}

Um dos pontos que merece consenso de todas as forças políticas é a necessidade do alargamento das relações diplomáticas de Portugal, nomeadamente aos países do Leste, à África, Ásia e mundo Árabe. O primeiro país de Leste a mostrar-se interessado em reatar relações diplomáticas foi a Roménia, que toma a iniciativa de exprimir esse desejo em meados de Maio ${ }^{27}$, logo seguido dos restantes. Em Agosto estavam já normalizadas as relações com os principais países do Leste. Em Setembro, Mário Soares reafirmava em conferência de imprensa que se pretendia manter relações com todos os países sem excepção.

Kalinine é o primeiro embaixador da URSS em Lisboa, onde chega a 26 de Julho de 1974, precedido por um amplo contingente de outros funcionários diplomáticos e não diplomáticos. Os contactos com a China decorrem discretamente em Paris, havendo a preocupação mútua de não mencionar sequer o nome de Macau, pois é evidente que Pequim não pretende qualquer revisão do estatuto do território por enquanto. Não vamos acompanhar este amplo e rápido processo. Basta referir à laia de resumo que, entre 1973 e 1979, se passou de 6 missões diplomáticas junto de organismos internacionais e 68 junto de Governos, para respectivamente 11 e 114, o que é quase o dobro (de 74 para 125) e revela bem o que foi a abertura de Portugal ao mundo.

27 Aparentemente, Álvaro Cunhal, consultado sobre o assunto, limitou-se a referir que se devia dar prioridade à URSS no reatamento das relações com o Leste da Europa. 


\subsection{A posição inicial dos polos do sistema}

Os EUA são uma preocupação central dos vários centros de poder do novo regime. Na última fase de Marcelo Caetano era visível uma aproximação com os EUA depois das cedências feitas durante a crise de $1973^{28}$, mas Washington não abria mão dos pontos centrais da sua política definida em 1959 e continuava a condenar verbalmente a recusa de aceitar a autodeterminação e a não fornecer armamento para África, nomeadamente os mísseis anti-aéreos individuais Redeye, considerados essenciais para a Guiné. Os EUA há muito que tinham deixado de votar contra Portugal na ONU (abstinham-se como regra) e a administração mostrava boa vontade em fornecer tudo que não pudesse ser considerado directamente armamento para África, embora em quantidades consideradas insuficientes. As relações, em resumo, eram das melhores desde 1961, mas com fortes agravos pelo lado português que não se sentia compensado pelos perigos assumidos. $O$ ressentimento era evidente nos últimos meses da administração de Marcelo Caetano.

Para Kissinger, de qualquer modo, Portugal e o sul da Europa eram uma zona tranquila e estável que não levantava problemas. Tudo indica que 025 de Abril apanhou a Embaixada americana e os serviços de informação de surpresa, numa altura em que Nixon entrava já na fase final do mandato e no momento mais aguda do trauma pós-vietname. Em Lisboa tinha sido recentemente colocado o Embaixador Scott, jurista simpático de avançada idade, que não era da carreira e esperava um lugar tranquilo num país acolhedor e soalheiro.

A primeira reacção americana parece ter sido de surpresa e expectativa. 025 de Abril revestia aspectos favoráveis do ponto de vista de Washington em termos do fim da guerra de África e da democratização de Portugal, mas a ascensão comunista e a instabilidade que vinha lançar no Sul da Europa e na África Austral eram uma nuvem negra de mau agouro, numa altura em que a vontade de empenhamento externo da administração era mínima. As garantias imediatamente dadas por Spínola e Mário Soares de que nada seria alterado nas relações com os EUA e com a NATO e a continuação de Hall Themido na embaixada de Washinton terão contribuído para amortecer os piores receios americanos e para a adopção de uma política inicial de «wait and see».

Mário Soares, por exemplo, frisa no discurso de Junho de 1974, na conferência ministerial normal da NATO, a intenção portuguesa de se manter fiel aos compromissos com a organização, o que não merece a contestação de qualquer partido político importante, nem sequer do PCP. Passados uns meses ${ }^{29}$ repete num discurso na ONU que a integração de Portugal na NATO é um dos «princípios fundamentais» da sua política externa.

28 Portugal foi o único aliado dos EUA a permitir o uso de uma base (as Lajes) para a ponte aérea para Israel na altura mais difícil da guerra com os Árabes.

${ }^{29}$ Em Setembro de 1974. Ver os respectivos discursos em Mário Soares, Democratização e Descolonização, Lisboa, 1975, pp. 43-50 e 123-137. 
O Embaixador Scott desde muito cedo começa a enviar para Washington uma análise dos acontecimentos moderada, onde o perigo comunista é subalternizado e o 25 de Abril apresentado como essencialmente positivo. Os seus conselhos vão no sentido de apoiar o general Spínola e as forças democráticas de forma discreta, sobretudo no campo financeiro, sem nenhuma atitude pública que se possa considerar como ingerência evidente.

O primeiro sinal sério de alarme para Washinton parece ter sido a cimeira Nixon - Spínola, feita a pedido e por insistência deste último, numa escala técnica do avião presidencial nos Açores. Spínola traça um quadro francamente negro da situação portuguesa, onde apresenta o país prestes a cair nas mãos dos comunistas e recorda a importância estratégica dos Açores e de Cabo Verde, para acabar por pedir um firme apoio americano à política de descolonização portuguesa e às forças que se organizam à sua volta no sentido de resistir à ofensiva comunista ${ }^{30}$. Nixon, possivelmente surpreendido pelo tom e com outras preocupações para ele mais importantes, limita-se a ouvir e a fazer algumas declarações de boas intenções, sem qualquer compromisso firme.

A partir de Julho de 1974 há sinais de que Washington começa a ficar preocupada com os acontecimentos em Portugal e procura rever a política, iniciativa que parte de Kissinger. O estímulo vem dos acontecimentos no Sul da Europa, com a queda da ditadura grega e a evolução na Espanha e Itália. De repente, Portugal deixa de ser um caso bizarro, para passar a ser um exemplo e o eventual começo de uma «queda» em movimento de peças de dominó de todo o Sul da Europa. Kissinger dá instruções a Scott pela primeira vez para fazer sentir a condenação americana da presença de ministros comunistas no Governo, mas ainda mantém no essencial a política de «wait and see».

O diálogo americano estabelece-se prioritariamente nesta fase com Spínola, com manifestações de desconfiança em certos meios em relação à Mário Soares, apesar dos anteriores contactos de longa data com a administração americana. Tudo indica que é em Julho que os EUA decidem finalmente reforçar a sério os serviços de informação e activar os canais de comunicação com instituições chave (militares, Igreja e partidos). É normal, mas não confirmado documentalmente, que estivessem também preocupados com o estabelecimento das relações diplomáticas com a URSS e com o crescimento imenso dos serviços soviéticos em Por-

30 O encontro foi pedido directamente pelo general Spínola a Scott a 11 de Junho e realiza-se a 19 desse mês, nos Açores. Spínola não convida Mário Soares para o acompanhar (como seria normal) e faz questão em levar Sá Carneiro, Ministro sem pasta. O Presidente da República, porém, insiste para que o encontro com Nixon seja a sós, tendo somente o testemunho do interprete americano. As actas americanas da conversa foram publicadas por José Freire Antunes (Os Americanos e Portugal, Lisboa, 1986, p. 340-342). O encontro obedece à política de Spínola de se procurar afirmar como o pivot do diálogo com o mundo ocidental e a escolha de Sá Carneiro para o acompanhar aponta para a sua opção estratégica de fomentar o desenvolvimento das forças à direita do Partido Socialista e subalternizar a aliança com este na resistência ao comunismo. Esse foi o principal erro político do general Spínola, que tinha na base uma ideia exagerado do seu poder pessoal e uma incompreensão sobre o movimento popular que estava em curso e excedia em muito os planos ou controlo do PCP. 
tugal, oficiais e não oficiais. É claro que quando Scott transmite as preocupações do seu Governo com a presença dos comunistas no Governo a Spínola este é o primeiro a dizer que também ele está preocupado, tal como transmitiu a Nixon nos Açores e reitera os pedidos de ajuda americana. O que Spínola não podia fazer era afastar os ministros comunistas do Governo ${ }^{31}$, nem tal era aconselhável nesta fase.

Depois deste primeiro sinal de mudança da política americana parece ter havido uma paralisação nos essenciais meses de Agosto e Setembro, o que é normal, pois Nixon resigna ao mandato a 1 de Agosto. A demissão de Spínola em fins de Setembro é acompanhada por um discurso pessimista que causa abalos externos evidentes ${ }^{32}$. Os efeitos nos EUA parecem ter sido especialmente fortes, tendo nomeadamente feito triunfar a «visão pessimista» no Departamento de Estado. Kissinger passa a não esconder a sua opinião de que o caso português está a resvalar perigosamente. Surgem os primeiros e preocupantes sintomas de falta de sangue frio da administração americana, com atitudes desastradas e pouco eficazes ${ }^{33}$. É notório um imediato recuo americano, patente no facto de cessarem as negociações para a ajuda. Kissinger e o SD inclinam-se já para a visão pessimista, mas ainda hesitam sobre a melhor política a seguir, em larga medida porque não entendem o processo português.

\section{A DEMOCRATIZAÇÃO COMO EIXO CENTRAL (SETEMBRO DE 1974 A NOVEMBRO DE 1975)}

\subsection{A luta pela alma de Portugal}

A segunda fase das relações externas da transição é marcada pela luta pela vitória do regime de democracia pluralista como eixo central. É um assunto interno, mas será ele o fio condutor de todas as relações com o exterior uma vez decidida a política da descolonização (o que no essencial está feito em Setembro) e até ao 25 de Novembro. Portugal foi o último país da Europa Ocidental onde aparentemente se deu uma tentativa de implantar um regime comunista, ainda por cima através de um modelo que parecia decalcado a papel químico da revolução de Outubro - onde nem sequer faltava uma guerra e um «Kerensky», como o próprio Kissinger referia. Portugal foi uma espécie de laboratório e de caso exemplar

31 Como o Dr. Mário Soares explicou várias vezes, o PS era o primeiro a não querer o afastamento dos comunistas do Governo antes das eleições, pois tal nas circunstâncias implicava que o PS seria muito prejudicado em termos de votos e que a oposição de rua ao executivo se iria agudizar.

32 Costa Gomes refere ( $O$ Último Marechal, p. 259) que vários países, entre os quais a França, Inglaterra e Alemanha, suspenderam os programas de apoio económico e financeiro em curso depois do discurso.

${ }_{33}$ Hall Themido (op. cit., p.194) refere que Alen Lukes, responsável do «desk» da Península no Departamento de Estado, telefonou para a Embaixada num domingo à noite para transmitir a preocupação com os acontecimentos em Portugal, uma actuação muito anormal e despropositada no mínimo. 
pela negativa para todas as revoluções democráticas posteriores. É uma luta pela alma de Portugal da qual tudo o resto depende, nomeadamente a forma de ligação ao mundo.

Há quatro grandes possibilidades em termos do tipo de regime para Portugal, todas com os seus defensores internos e externos: uma democracia representativa pluralista do tipo da Europa Ocidental, uma ditadura comunista do tipo soviético, um regime autoritário de direita, mais ou menos próximo da democracia e um regime dito de democracia «populista» ou terceiro mundista, vago e indefinido, para o qual se dão os mais diferentes tipos de exemplos, desde a Jugoslávia ao Peru. A dificuldade das forças democráticas era não só a de derrotarem a aparente tentativa de tomada de poder pelos comunistas, mas sobretudo, o fazerem-no de tal maneira que afastassem a possibilidade de outro tipo de regime que não a democracia pluralista representativa de tipo ocidental. Tal passava nomeadamente por dissuadir as atitudes mais radicais da Espanha ou dos EUA, que poderiam levar à instalação de um regime conservador não democrático. $O$ regime comunista era de todas as possibilidade a que tinha menos hipóteses reais, pois mesmo que se instalasse não duraria certamente muito tempo. Esclareço que, para efeitos deste texto, não interessa saber se houve realmente ou não uma tentativa de assalto ao poder consciente pelo $\mathrm{PCP}^{34}$. O que interessa é que durante a fase considerada era essa a aparência, $\mathrm{O}$ que condicionava as relações externas do país a todos os níveis.

Todos os modelos mencionados tem as suas referências e apoios além fronteiras e as forças nacionais empenhadas no processo procuram obter a ajuda possível do exterior, como é normal. É um período em que as relações internacionais passam no essencial por outras vias que não o Ministério dos Negócios Estrangeiros, algumas das quais ainda não se conhecem hoje. Uma das mais importantes são os partidos e o seu financiamento, em especial o PCP, com a ligação ao PCUS, e o PS, com a ligação à Internacional Socialista, que governa nesta altura os principais países da Europa Ocidental. Portugal está no centro da atenção do mundo, ocupa o primeiro lugar nos noticiários e até uma revista como a Time lhe dedica capas ${ }^{35}$. Interessa examinar por alto a forma como este processo complexo se reflecte nas relações com as principais referências externas portuguesas.

34 Numa opinião pessoal, o processo da revolução portuguesa foi demasiado espontâneo e vasto para se poder dizer que alguém o controlava ou dirigia de forma consciente. Os quadros mais experientes do PCP tentaram desde o primeiro momento aproveitar a situação, assegurar a tomada de posições e a alteração das estruturas políticas e económicas de modo a caminhar-se para uma ditadura comunista, mas inicialmente sem uma intenção clara de tomar o poder. É para mim evidente que, a partir de começos de 1975, alguns elementos dirigentes do PCP acalentaram as esperanças de ser possível «queimar etapas» e tomar o poder a curto prazo. No entanto, penso igualmente que os elementos mais realistas se aperceberam que uma tentativa de tomar o poder se saldaria por um fracasso com um inevitável banho de sangue e, sobretudo, que não teria o apoio do Governo Soviético. A partir daí, a estratégia dominante foi a de negociar o recuo, abandonando e sacrificando, é claro, os «companheiros de caminho" de sangue mais quente, que tiveram a triste ideia de confiar em tais aliados numa altura de crise e pagaram o preço.

${ }_{35}$ É um famoso número de Agosto de 1975, com a capa preenchida por três fotografias (Otelo, Costa Gomes e Vasco Gonçalves), classificados da «troika vermelha» que dominava Portugal. 


\subsection{A divisão dos EUA e a NATO}

Em relação aos EUA, depois de Setembro de 1974 instala-se a visão pessimista sobre a evolução portuguesa no Departamento de Estado. Kissinger ainda alimenta algumas dúvidas e envia várias «missões de estudo» directas e indirectas a Portugal, onde se destaca a missão Lukens em Outubro desse ano. Esta confirma em larga medida a análise do Embaixador em Lisboa e, pela primeira vez na administração americana, segundo penso ${ }^{36}$, defende que o PS é o centro à volta do qual se podem organizar as forças democráticas para resistir ao avanço comunista, tese que Secretário de Estado não subscreve nesta altura apesar das pressões dos países da Europa Ocidental nesse sentido. Logo em Outubro, a visita de Costa Gomes e Mário Soares a Washington mostra bem o clima das relações existentes, quando se regista um diálogo tenso à mesa do almoço. Kissinger deixa entender claramente que considera Portugal um caso perdido e que Mário Soares será o «Kerensky» português. Sá Carneiro visita Washington em Novembro e mantém contactos no Departamento de Estado e noutros sectores.

Kissinger afasta-se da análise e recomendações do Embaixador Scott, que continua a defender que a democracia se acabará por impor e que o Governo americano não deve fazer nada oficialmente, limitando-se a apoiar as forças democráticas por vias indirectas tão discretas quanto possível, nomeadamente através da RFA e dos países nórdicos. Scott será substituído por Frank Carlucci em Novembro de 1974. O novo embaixador chega com a fama de ser um homem para as crises com ligações a outras instituições que não somente o Departamento de Estado, o que provoca um importante incidente quando Otelo diz aos jornalistas que, tendo isso em conta, não garante a sua segurança ${ }^{37}$. Para surpresa de Kissinger, Frank Carlucci faz uma análise muito semelhante a de Scott sobre a situação portuguesa, e defende que o PS e Mário Soares devem ser considerados o centro civil da resistência ao avanço comunista e tratados enquanto tal. O novo embaixador, porém, tem um estilo muito diferente do calmo e pouco expansivo Scott e a vantagem de falar um bom português, com sotaque brasileiro. A partir de fins de Novembro, os contactos das instituições que funcionam com o apoio da Embaixada multiplicam-se a todos os níveis, não só em termos das forças políticas democráticas, mas igualmente dos militares, da igreja e dos sindicatos. Frank Carlucci adapta-se facilmente ao temperamento e

\footnotetext{
${ }^{36}$ Ainda se está longe de conhecer a totalidade dos documentos americanos deste período, pelo que as afirmações deste tipo são sempre provisórias e só a abertura futura dos arquivos a permitirá confirmar ou não. É, no entanto, muito significativo sobre a sensibilidade muito diferente dos dois países em relação a estes assuntos, que hoje já conhecemos uma parte dos documentos americanos sobre Portugal em 1974/76, mas ainda não conhecemos os documentos do MNE português, o que também não tem grande importância, pois os contactos externos realmente importantes não passavam por ali.

37 As afirmações surgem no período mais quente da revolução portuguesa, no seguimento do 11 de Março. Costa Gomes imediatamente manda pedir desculpas e apresenta as justificações possíveis, mas tal não impede um protesto formal dos EUA. Carlucci tem uma reacção típica e limita-se fleumaticamente a convidar Otelo Saraiva de Carvalho para um almoço, sem dar importância às afirmações ou aos protestos.
} 
estilo latino dos portugueses e os seus dotes pessoais são importantes para entrar em sectores onde os EUA até aí praticamente não tinham mantido contactos. Ainda é cedo para fazer a história minimamente completa da sua missão em Lisboa, mas não deixa de ser interessante para dar um exemplo do estilo pouco tradicional, mencionar meramente que dias antes do 25 de Novembro o Embaixador dos EUA fez uma digressão oficial pelo Norte do País, onde manteve contactos directos com os bispos, autoridades militares, governadores civis, presidentes das Câmaras e outras instituições, tudo com o pretexto de apoiar a instalação dos retornados.

É normal colocar em completa oposição as análises e atitudes de Kissinger e Frank Carlucci, mas a verdade é que elas tinham muito de complementar. Não é por acaso que Kissinger não só envia como mantém Carlucci em Lisboa. O Secretário de Estado do Presidente Ford pensava em termos globais, preocupado com a evolução de todo o sul da Europa a partir de Julho de 1974 e com a penetração soviética em África desde Setembro desse ano. Actuava com fortes condicionalismos internos e sob apertada vigilância do Congresso, o que lhe retirava muitos dos meios tradicionais de acção dos EUA . Não escondia o seu pessimismo sob a evolução do caso português e talvez isso o tenha levado a atitudes algo bizarras e de pouco sangue frio, como seja a apresentação de um protesto quase oficial quando Mário Soares abandona as Necessidades, algo pouco curial nas relações entre Governos. Mas, se é certo que assumia estas atitudes, aceitou no essencial as recomendações de Scott e Frank Carlucci sobre a política para com Portugal: não intervir de forma directa (conselho nem sempre respeitado, como o protesto mencionado prova), não fazer declarações públicas, apoiar discretamente as forças democráticas, não incentivar as independências insulares.

Do ponto de vista americano e considerando o problema em termos globais, a evolução de curto prazo portuguesa era relativamente indiferente. Kissinger e os responsáveis americanos sabiam que, se tudo corresse pelo pior e o país resvalasse para um regime comunista, seria uma experiência que pouco duraria e muito possivelmente terminaria com uma guerra civil facilmente ganha, até talvez sem ajuda externa directa, embora esta estivesse disponível em caso de necessidade. De qualquer modo, sabiam também que os Açores e a Madeira nunca aceitariam um regime comunista, pelo que a zona estrategicamente mais importante para eles estava salvaguardada. É a essa luz que se tem de entender a famosa «teoria da vacina» de Kissinger, segundo a qual a vitória comunista em Portugal seria uma forma radical de impedir uma evolução semelhante em qualquer zona do Sul da Europa. De qualquer modo, a melhor política para o Secretário de Estado era, independentemente do seu pessimismo, escolher um embaixador que fizesse o possível para apoiar a vitória das forças democráticas em Portugal, dentro das fortes limitações da administração americana nesta altura, enquanto ele preparava as coisas para ter uma resposta preparada se tudo corresse pelo pior. Foi justamente isso que fez, numa política conjugada com Carlucci, embora a aparência fosse justamente o contrário. 
É a essa luz que se tem de entender a política para com o separatismo Açoriano: o Governo Americano não o incentivava nem promove, o que teria sido muito fácil de fazer se fosse essa a opção; no entanto, o Governo Americano aceita que outras instituições que não ele directamente mantenham os movimentos independentistas em «lume brando». Eram uma espécie de bóia de salvação, caso tudo corresse pelo pior, o que estava dentro das perspectivas pessimistas de Kissinger (que controlava igualmente os serviços de informação). É necessário acrescentar que durante esta fase a ajuda directa americana às forças democráticas foi reduzida e discreta, bastante menor que a proveniente da RFA, por exemplo. No entanto, há que ter em conta que pelo menos uma parte da ajuda da RFA tinha a sua origem nos EUA.

O 1. ${ }^{\circ}$ Governo Provisório reafirma rapidamente a adesão de Portugal à NATO e aos seus princípios por iniciativa de Mário Soares. A NATO tem uma acção importante mas discreta a favor da vitória da democracia, principalmente pela sua acção junto dos meios militares. No período do verão quente são os próprios portugueses que se afastam dos centros de planeamento da NATO mais sensíveis, nomeadamente do planeamento nuclear onde Costa Gomes tinha participado, de modo a evitar receios de «espionagem» a favor dos comunistas.

A questão da saída de Portugal da NATO nunca se coloca, embora tenha pairado no ar por várias vezes. Os EUA nomeadamente deram a entender no período do $5 .^{\circ}$ Governo que um país com um executivo dominado pelos comunistas não podia continuar a fazer parte da NATO. Portugal, por seu lado, deu a entender por iniciativa de Mário Soares, que a única coisa que poderia obrigar o país a rever a sua participação na NATO era o eventual apoio americano aos movimentos independentistas insulares. Qualquer das ameaças não teve seguimento. Portugal

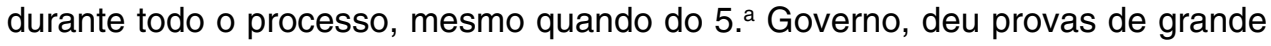
contenção em termos das acções no seio da NATO, nomeadamente na gestão da permanência americana nas Lajes. Durante esta fase o cumprimento dos compromissos e obrigações em termos militares passou pelo pior período, com uma participação mínima nos exercícios comuns, mas nunca cortada por completo.

A enquadramento na NATO funciounou como um dos mais importantes factores moderadores mútuos - efectivo tanto em termos de Portugal como dos EUA. Os aliados europeus da NATO, por exemplo, pressionaram Washington para que moderasse a política em relação a Portugal e combateram no seio da organização o pessimismo de Kissinger sobre a evolução portuguesa. A influência da instituição foi particularmente importante no seio dos militares portugueses, um dos elementos essenciais de todo o processo.

\subsection{A divisão da URSS}

A URSS, segundo é possível avaliar no actual momento, tem uma evolução semelhante ao caso americano. A revolução portuguesa aparentemente é uma sur- 
presa para Moscovo. Surge num momento em que, como já referimos, o eixo central da política russa para a Europa Ocidental era o de não provocar confrontos directos e provas de força, como forma de incentivar a autonomia dos europeus, apostar nas relações financeiras com a Europa Ocidental e no processo da Conferência de Helsínquia, de onde acabaria por sair a OSCE. Nada disto era compatível com a perspectiva de um regime comunista em Portugal que, mesmo que fosse possível instalar, se teria de manter rodeado dos EUA de um lado e de uma Europa Ocidental hostil do outro, a começar pela Espanha. Um tal regime, em resumo, precisaria de contar desde o primeiro momento com um empenhamento directo e muito forte da URSS e seria sempre uma fonte de conflitos com os EUA e a Europa. Iria igualmente contribuir para mandar a Europa Ocidental de novo para os braços da iniciativa americana e acabar com a Ostpolitik, antes mesmo de ela ter começado a sério. Além do mais, a sua sobrevivência seria muito duvidosa em termos da inevitável guerra civil e era quase certo por uma aritmética elementar que acabaria numa imensa derrota, que só uma intervenção militar em larga escala poderia evitar. Moscovo, porém, sabia perfeitamente que não era possível montar em Portugal a intervenção que fez futuramente em Angola, pois tal nunca seria permitido pelos EUA, pela NATO e pela CEE.

Ao mesmo tempo, porém, a revolução portuguesa surge no seguimento de um amplo debate sobre as «lições do Chile», onde a tendência era para concluir que o principal erro dos comunistas foi o de acreditarem na transição pacífica e não terem procurado conquistar a tempo as alavancas centrais do poder do Estado e destruir as posições dos seus adversários. O 25 de Abril dá-se ainda no país da Europa Ocidental que tinha um partido comunista mais próximo de Moscovo, talvez mesmo mais stalinista que a administração soviética, com óptimas relações com o PCUS. Mais do que isso, a revolução portuguesa tem muito de espontâneo e em toda a primeira fase as suas principais manifestações (como as ocupações, a auto-gestão, a recusa dos embarques, a dissolução da disciplina militar) pouco tem a ver com o PCP. São estes movimentos, porém, que criam uma dinâmica e uma «janela de oportunidade». A partir de certa altura sectores da direcção do PCP pressionam para «queimar etapas» e avançar para a conquista do poder, especialmente quando se convencem com as eleições de Abril de 1975 que o partido em democracia seria sempre pequeno e marginal. Estas opiniões tiveram um eco em sectores da direcção do PCUS, que tendiam a ver Portugal como uma repetição de Outubro de 1917 e, sobretudo, chamavam a atenção para o facto do exemplo do Chile ter «provado» que hesitar e aceitar o meio caminho era abrir o caminho à contra-revolução, com o banho de sangue para os comunistas. Eram posições defendidas por nomes como Ponomariev e Suslov, que simpatizavam com a ideia de uma tomada do poder pelos comunistas em Portugal e pensavam que era possível uma segunda Cuba na Europa Ocidental, apesar das condições difíceis.

Tudo indica, em resumo, que durante o verão quente também a administração soviética se divide. Em última instância o Governo não deseja um regime 
comunista em Portugal por razões de estado, posição assumida por Gromyko e Brejnev, mas não tem a força nem os argumentos para calar por completo os sectores mais entusiastas do PCUS. Tal como aconteceu com os EUA, acaba por prevalecer uma política de «wait and see», onde se mantém várias possibilidades em aberto. È isso que explica que Gromyko tenha garantido formalmente a Mário Soares que o Governo Russo não apoiava qualquer tentativa de tomada do poder pelo PCP, mas, ao mesmo tempo, tenha acrescentado que não podia garantir que não houvesse entendimentos nesse sentido de outra origens ${ }^{38}$.

A política de manter várias possibilidades em aberto, aliás, só trazia vantagens à URSS, pois correspondia à real divisão interna, permitia rever a posição se, contra as previsões, a Europa do Sul começasse a dar sintomas claros de viragem para Moscovo (o que era muito pouco provável mas não impossível, tendo em conta a incógnita do caso espanhol) e, mais importante do que isso, permitia negociar um recuo na altura devida, tanto com os EUA como com a CEE. Implicava certamente um custo e um risco, mas este era reduzido perante as potenciais vantagens. O custo passava nomeadamente pelo financiamento do esforço de implantação comunista em Portugal, que teria de ser suportado em qualquer circunstância, e o risco era a manutenção de um foco de instabilidade no Sul da Europa. O grande perigo era que o processo pudesse derrapar ou que provocasse uma reacção demasiado forte dos EUA, mas a política de desprendimento e aparente desinteresse de Kissinger dava garantias de que tal não aconteceria. Em resumo, mesmo para o Governo soviético era preferível manter por um certo período a aparência de uma real tentativa de tomada do poder pelos comunistas em Portugal, até como forma de condicionar a evolução em África, embora tal não correspondesse às suas intenções.

Neste sentido, podemos dizer que Gromyko e Kissinger tem um papel muito semelhante no que diz respeito ao caso português: ambos são orientados por razões de estado, querem evitar os confrontos directos perigosos, subordinam o problema a um enquadramento global e têm de aguentar a pressão dos sectores mais extremistas e radicais das respectivas administrações, que defendem um maior empenhamento em Portugal - em sentidos opostos evidentemente. Ambos tratam o verão quente como uma crise controlada que pode trazer vantagens, apesar do perigo que representa e do factor de imprevisibilidade que envolve.

\subsection{A posição espanhola}

A partir de Setembro de 1974 as relações com a Espanha entram igualmente numa nova fase. Madrid mostra-se preocupada com a evolução da situação portuguesa mas não altera no essencial a sua política de não ingerência nem de permitir acções que partam de forma clara do país vizinho. Aceita, porém, a instalação

38 Entrevista de Mário Soares com Maria João Avillez, op. cit., p.180. 
no seu território de um número crescente de refugiados do campo conservador e auxilia mesmo a sua organização, inclusive com a formação de campos de treino militar longe da fronteira portuguesa (houve pelo menos dois: um no Vale dos Caídos e outro em Ávila). Há igualmente indicações, que não é possível confirmar de forma segura, que antes do 11 de Março teriam sido dadas garantias a dirigentes do ELP e do futuro MDLP que um Governo de direita em Portugal seria rapidamente reconhecido pela Espanha, mesmo que só controlasse uma parte do território ${ }^{39}$.

A situação pior das relações com a Espanha corresponde ao período entre o 11 de Março e a formação do 6. ${ }^{\circ}$ Governo Provisório, a 19 de Setembro de 1975. Há então sérios receios em sectores importantes do Franquismo sobre a implantação de um regime comunista em Portugal, pelo que se acentua a política de permitir e mesmo auxiliar a organização da oposição conservadora em Espanha. Chegam a ser fornecidas armas e equipamento militar. São mesmo permitidas algumas acções em Portugal, especialmente quando começa a vaga de assaltos às sedes do MDP e PCP no norte do país - que é uma operação de «frente coligada», onde inúmeras forças democráticas e não democráticas estão envolvidas, inclusive sectores da chamada extrema esquerda. No entanto, a linha continua a ser clara: no essencial não se incentivam nem autorizam acções que de forma evidente sejam lançadas a partir da Espanha, não se hostiliza directamente o Governo de Lisboa e procura-se reforçar os contactos e as vias do diálogo. Segundo tudo indica, a análise da Embaixada Espanhola em Lisboa foi sempre no sentido de prever a vitória das forças democráticas.

As autoridades portuguesas fomentavam esta tendência moderando dentro do possível as acções anti-franquistas em Portugal, mas permitindo igualmente o afluxo de refugiados e uma certa organização destes. Chegaram mesmo a ser feitos a anunciados publicamente acordos formais de que não se daria cobertura a acções de desestabilização de um regime a partir do território do outro, que pouco mais eram que uma declaração de intenções e valiam o normal nestas circunstâncias ${ }^{40}$.

A Espanha em resumo, tal como acontece com as duas superpotências, define uma política oficial de moderação, apoio modesto às forças conservadoras (não as forças democráticas), recusa de acções que partam do seu território, mas, ao mesmo tempo, prepara as condições para poder activar uma política contrária, caso seja necessário. Era uma espécie de seguro para o futuro, pois havia muito de imprevisível e surpreendente na evolução portuguesa. Se tudo corresse pelo pior, ao contrário do que se previa, teria sido muito fácil para o Governo de Franco montar em pouco tempo uma incursão ou apoio armado a partir do

\footnotetext{
39 Ver nomeadamente Cervelló, op. cit., p. 351.

40 Mário Soares anunciou publicamente um acordo nesse sentido a 24 de Dezembro de 1974 e Melo Antunes refere que, no encontro com o MNE espanhol em Junho de 1975, o acordo foi confirmado. Ver Cervelló, op. cit., p. 352.
} 
seu território às forças anti-comunistas, meramente com as organizações portuguesas que já existiam além raia.

Depois da formação do 6. ${ }^{a}$ Governo Provisório (Setembro de 1975) Madrid parece convencida da vitória final das forças moderadas em Portugal e reduz o apoio às organizações que operam em Espanha, nomeadamente em termos de fornecimento de material militar. A grande prova da moderação espanhola surge em fins de Setembro de 1975, quando grupos de manifestantes assaltam as instalações da Embaixada e dos dois principais consulados espanhóis, a pretexto da condenação à morte de 5 anti-franquistas. É um movimento que nada tem a ver com o Governo Português ou mesmo com a direcção do PCP. A sua origem não é clara, parecendo ter obedecido sobretudo ao clima apaixonado vigente e a estímulos de certas organizações, sendo um exemplo de como o processo português podia derrapar com relativa facilidade. Melo Antunes imediatamente condena os acontecimentos e manifesta a disponibilidade portuguesa para pagar todos os estragos, pois felizmente não houve danos pessoais de maior monta. Para surpresa de muitos, Madrid mostra-se extremamente compreensiva e logo declara que o facto não alterará as relações entre os dois estados, aceitando o pagamento de uma muito generosa indemnização.

O afastamento do general Franco da governação por razões de saúde em Outubro de 1975 e o seu falecimento pouco antes do 25 de Novembro ainda reforçam mais o que era já a política oficial espanhola. A partir de Dezembro de 1975, quando D. Juan Carlos é proclamado Rei de Espanha, Madrid acaba com os campos de treinos e deixa de apoiar a oposição conservadora portuguesa, mesmo em termos de um seguro para o futuro.

A transição portuguesa funcionou, como José Sanchez Cervelló muito bem refere, como uma espécie de vacina para a Espanha, interpretação que foi confirmada pessoalmente por Santiago Carrilho na intervenção que recentemente fez em Lisboa ${ }^{41}$. Ela encorajou a transição menos conturbada da Espanha e desfez 0 incentivo para a crispação do regime que poderia resultar de uma vitória comunista em Portugal.

\subsection{A acção da Europa ocidental}

Deixei para o final o que penso ser a mais importante influência externa em Portugal nesta fase: a da CEE e dos países da Europa Ocidental. A aproximação com a CEE começou logo a seguir ao 25 de Abril pela digressão de Mário Soares pelas capitais europeias, a 2 de Maio, ainda antes de ser nomeado Ministro dos Negócios Estrangeiros. Duas prioridades desta primeira fase são a ob-

41 No encontro sobre a transição espanhola, organizado pelas Fundações Mário Soares e BBV na Torre do Tombo, em Outubro de 1998. 
tenção de financiamento para o Estado e o aprofundamento das relações comerciais. O tratado de comércio assinado em 1972 previa a existência de uma comissão mista que se reuniria regularmente para fazer um balanço da situação e aprofundar as relações comerciais. Na primeira reunião depois do 25 de Abril (em fins de Junho de 1974) Portugal faz-se representar por Palma Carlos e Mário Soares, que afirmam que o país se pensa reger pelos princípios democráticos da CEE, o que era já considerado por Bruxelas uma condição prévia para qualquer aprofundamento das relações. O apoio financeiro de Bruxelas e da Europa tornase ainda mais importante quando, logo em Julho de 1974, falha o muito substancial crédito de 400 milhões de contos que estava a ser negociado com o Banco Mundial, enquanto os EUA só abrem mão de pequenas quantias sem grande significado.

A partir de Setembro de 1974, quando se torna claro que começou uma ofensiva comunista, os principais dirigentes europeus encaminham-se regularmente para Portugal, normalmente trazidos pela mão do PS, mas também do PPD e CDS. Willy Brandt e Olaf Palme visitam o país em fins de Outubro e pouco depois Vítor Alves parte de mão estendida para mais uma digressão pelas capitais europeias, enquanto se pede um alargamento das trocas comerciais com o revisão do acordo de 1972. O primeiro Congresso do PS na legalidade, em Dezembro de 1974, é uma verdadeira montra dos países europeus, com a presença de Miterrand e de delegações de muitos outros países, onde a espanhola era especialmente forte, nem sequer faltando Santiago Carrilho para dar a legitimidade dos eurocomunistas à luta pela democracia em Portugal.

O coração do apoio europeu às forças democráticas portuguesas era a Internacional Socialista e, muito em especial, a RFA e a Suécia. A Inglaterra de Wilson e Galaghan dava uma apoio político caloroso e activo, mas faltavam-lhe os recursos financeiros da Alemanha. Foram, porém, para citar só um exemplo, operacionais ingleses que ajudaram a montar certos aspectos das operações militares previstas pelo grupo dos nove. Algo de semelhante, em menor escala, faziam a Itália, Noruega e Holanda. Bona, directa ou indirectamente, através de fundações e múltiplas instituições semi-públicas ou privadas, era a grande fonte de financiamento externo de muitas organizações portugueses, desde o PS, aos outros partidos democráticos, associações de agricultores, sindicatos e, segundo parece, até mesmo sectores ligados à Igreja. Aqui não havia as reservas dos meios americanos que tinham de começo certo receio do PS e da menção da mera palavra «socialista». Pelo contrário, os países da CEE não hesitaram em escolher o PS para parceiro privilegiado em Portugal e, com isso, deram um importante contributo para a afirmação interna de Mário Soares e do seu partido como centro civil do movimento de resistência, que era uma avassaladora e irresistível onda de fundo, mas uma onda que levava tempo a ganhar força e a organizar-se.

A RFA e a CEE dariam a nível governamental directo apoio financeiro ao processo português até muito tarde, apesar da ofensiva comunista ser especial- 
mente evidente desde o 11 de Março. Em começos de Abril de 1975, por exemplo, a RFA aprova uma nova fatia de crédito de 70 milhões de marcos. A situação só muda com a formação do $5 .^{\circ}$ Governo, a 8 de Julho de 1975 . Então é a França que expressamente veta o grande financiamento que estava a ser discutido com a CEE, pois, segundo diz não pretende auxiliar um governo comunista. Bruxelas paralisa as negociações em curso e avisa expressa e publicamente os responsáveis portugueses que o seu apoio só continua caso se caminhe para um regime democrático e pluralista. $\mathrm{O}$ Conselho Europeu publica em meados de Julho um relatório onde coloca a mesma condição para a continuação de uma ajuda de qualquer tipo. A posição é firme, embora não se tenham adoptado medidas mais radicais que chegaram a ser discutidas, como sejam a proibição das remessas dos emigrantes, o que seria um verdadeiro cheque mate na abalada economia portuguesa. Os apoios financeiros da CEE só recomeçam em meados de Setembro, quando Vasco Gonçalves cai e se forma o 6. Governo Provisório. Era já evidente que o bloco democrático iria vencer, embora faltasse o desenlace do processo.

A actividade europeia em apoio da democracia não revestia somente estes aspectos de intervenção directa. Vários Governos europeus, a começar na Inglaterra e na RFA, fizeram sentir aos EUA desde muito cedo que não concordavam com a visão pessimista de Kissinger sobre Portugal, que era impensável um corte com os governos portugueses (mesmo com o $5 .^{\circ}$ Governo), que não se aceitava um afastamento do país da NATO, que não se deviam adoptar posições radicais de apoiar o separatismo ou as forças mais à direita com um duvidoso espírito democrático e que se devia apostar no PS, PPD e CDS, mas com métodos tão discretos quanto possível. Esta política europeia junto dos EUA é especialmente importante. Não podemos esquecer que as alternativas do processo não eram somente um regime comunista ou um regime democrático. Havia outras e o pessimismo americano sobre as possibilidades das forças democráticas poderia ter levado a um apoio aos movimentos conservadores saudosos do antigo regime ou aos independentistas. A acção da CEE foi decisiva para impedir que tal acontecesse.

Pressões semelhantes foram feitas junto da URSS. Willy Brandt, por exemplo, refere nas suas memórias que foi expressamente a Moscovo no começo do verão de 1975 para avisar Brejnev das consequências muito negativas de uma «avaliação errada da situação no sul da Europa», em termos do novo clima que se pretendia cria no continente. Diligências semelhantes, embora com menos peso em Moscovo, foram feitas pela Inglaterra. Na Conferência de Helsínquia de Agosto de 1975, onde Costa Gomes representou Portugal, as diligências mais importantes para o país foram feitas pelos dirigentes europeus em peso (François Miterrand, James Callaghan, Helmut Schmidt, Olaf Palme, Bruni Kreisky e outros) que mais uma vez fizeram sentir a Brejnev que uma vitória comunista não democrática em Portugal poria em causa todo o processo então iniciado, para além de ter outras consequências. A pressão europeia no sentido da moderação foi ainda importante junto da Espanha e da África do Sul, como já referimos. 


\subsection{A vitória da via democrática}

A luta pela alma de Portugal estava no essencial decidida no 25 de Novembro, com a iniciativa bem sucedida dos partidários da democracia pluralista e representativa numa acção preparada de longa data, com o apoio discreto de alguns serviços europeus (Inglaterra, RFA) em termos militares. Era ainda uma democracia semi-militarizada, com muita participação da rua, mas era sem dúvida uma democracia, como ficou patente na forma como se ergueram as vozes dos principais responsáveis pelo processo a defender a manutenção do PCP como força política legal. A direcção central do PCP, aliás, é a primeiro a querer evitar um confronto aberto ou provocar uma guerra civil nesta fase adiantada, pois sabia que iria perder.

A vitória da democracia em Portugal foi no essencial um processo interno. $O$ seu motor foi a vaga de fundo que se ergueu a partir de Abril de 1975 contra a radicalização e o que era entendido como uma tentativa de tomada do poder pelos comunistas. Era uma vaga irresistível e espontânea, legitimada pela esmagadora vitória dos partidos democráticos nas eleições para a Constituinte. Foi uma vaga de fundo que ninguém organizou e dirigiu no sentido normal do termo, embora tenha sido inteligentemente fomentada principalmente por Mário Soares, pelo PS e por outras forças. Foi essa vaga que criou e deu dimensão aos políticos que a entenderam e a cavalgaram no momento oportuno. Isto não quer dizer que, na minha opinião, necessariamente as coisas se tivessem de passar como se passaram. Pelo contrário, era perfeitamente possível que, com outras pessoas, tivesse estalado uma guerra civil e que o resultado final não fosse uma democracia tipo Europeu, mas um regime autoritário e conservador. A única possibilidade que me parece francamente de excluir é a de um regime comunista minimamente estável. Este, mesmo que se instalasse em Lisboa (era impensável que ganhasse o país a norte de Rio Maior, no Algarve ou a Oeste do Cabo da Roca), teria uma vida curta, talvez medida meramente em horas.

O enquadramento exterior teve a sua importância no processo e favoreceu as forças democráticas, mas não foi de modo nenhum o decisivo. Também não era obrigatório que isso acontecesse. Basta recordar o caso de Angola, onde o factor essencial da evolução foi o externo, o que desencadeou no país uma guerra civil por procuração que se prolongaria por muitos anos.

\section{A EUROPA COMO EIXO CENTRAL (NOVEMBRO DE 1975 A MARÇO DE 1977)}

\subsection{Os desequilíbrios económicos externos}

Para compreender a importância efectiva da Europa nesta fase, será bom recordar que em 1973 a CEE (onde se incluía a Inglaterra) era a principal referência 
económica portuguesa, com um peso esmagador e uma importância relativa crescente. O comércio externo nacional é um bom exemplo: cerca de metade era feito com a CEE em 1973 (45\% das importações e 48\% das exportações), mais do triplo dos valores da África Portuguesa (10\% das importações e $15 \%$ das exportações). O que é mais, a CEE era a zona dominante do comércio externo português praticamente desde o tratado de Roma: em 1960, por exemplo, a CEE (ainda sem a Inglaterra) representava 39\% das importações e $21 \%$ das exportações, o que a colocava à frente da recém formada EFTA ( $20 \%$ das importações e $20 \%$ das exportações) e da África Portuguesa (14\% das importações e $25 \%$ das exportações). Das Comunidades vinham ainda mais de dois terços dos principais fluxos financeiros positivos que eram essenciais para manter a economia portuguesa, nomeadamente os créditos externos, investimentos, remessas de emigrantes e receitas do turismo. Na realidade, embora a África dominasse os discursos e as referências oficiais antes do 25 de Abril e embora a política externa portuguesa de então se articulasse à volta do eixo central de manter as colónias, a verdade é que a CEE era desde o começo dos anos 60 a grande referência nacional em termos económicos, humanos e até de influências culturais. A esmagadora maioria das novidades ideológicas e do pensamento desses agitados anos sessenta vinham de além-Pirinéus, sendo muito reduzida neste campo a influência dos EUA, da Espanha ou de África.

Era uma situação curiosa e bizarra em que as relações externas portuguesas estavam centradas na CEE, mas a política externa estava centrada em África, pela necessidade de aguentar as guerras. Depois do 25 de Abril, quando se agravam fortemente as dificuldades económicas, os países da CEE surgem como a grande tábua de salvação a curto prazo em termos comerciais e financeiros. Bruxelas mostra-se bastante mais generosa quanto a créditos governamentais do que os EUA, do mesmo modo que a RFA é mais generosa quanto a ajudas financeiras «privadas". A CEE, para satisfação das forças democráticas portuguesas, coloca de forma explícita uma condição: o país teria de evoluir para um democracia pluralista e representativa.

Este facto só por si bastaria para obrigar Portugal a transformar-se a prazo numa democracia representativa, pois era impensável perder os laços económicos privilegiados com a CEE, nomeadamente as remessas dos emigrantes, as receitas do turismo e os investimentos e financiamentos europeus, o que aconteceria caso se implantasse um regime comunista. A paralisação destes fluxos seria uma catástrofe económica e financeira de tais dimensões, que o nível de rendimento dos portugueses passaria de repente para o século passado. A única alternativa seria a URSS dar por longo prazo um financiamento ainda mais generoso do que o fornecido a Cuba, coisa que Moscovo não tencionava fazer. A crise financeira, porém, tarda a fazer sentir os seus efeitos e durante os meses do verão quente 0 país ainda consegue viver em termos financeiros dos fluxos normais das remessas e do turismo (embora diminuídos) e dos créditos que obtém aqui e ali, principalmente nos países da CEE. 
Depois do 25 de Novembro o combate à crise financeira torna-se uma prioridade, a par da modernização da economia. A balança de transacções correntes do país, que tinha um saldo positivo de 6,5 milhões de contos em 1973, passou a assumir crescentes valores negativos: $-24,5$ em 1974, $-25,1$ em 1975 e -43,9 em $1976{ }^{42}$. A situação ainda não era de ruptura financeira pois as reservas eram substancias e as remessas dos emigrantes continuavam em valores elevados, mas era sem dúvida alarmante. Foram de imediato adoptadas medidas de limitação às importação, redução das divisas que era possível trocar nos bancos e restrições à saída das pessoas, o que era suficiente para lembrar ao português comum as dificuldades prementes neste campo. O mais preocupante nas circunstâncias nem sequer era a crise financeira e económica, mas sim a tendência descendente da economia e a fuga de capitais, ambas difíceis de contrariar com meras medidas pontuais. A crise económica resultava parcialmente da conjuntura económica externa, do desfazer das estratégias empresariais existentes sem substituto à altura. A sua principal causa, porém, era a rotura dos anteriores equilíbrios, onde África cumpria o seu papel, sem que se tivessem construído novos. A situação económica e financeira tinha-se tornado o grande desafio para a democracia, da qual ia depender a sua estabilização.

\subsection{A importância da CEE} sável:

O problema exigia dois tipos de medidas e para ambas a CEE era indispen-

- a curto prazo, era necessária a adopção de uma política de austeridade e de obtenção de créditos externos e ajuda financeira de emergência;

- a médio prazo, era vital encontrar um novo equilíbrio dos fluxos económicos e financeiros do país.

Os dois aspectos estavam intimamente ligados e um não fazia sentido sem o outro. Em termos da procura de um novo equilíbrio era evidente, tendo em conta as ligações prioritárias da economia portuguesa de longa data, que tal teria de passar pela adesão à CEE. Era um passo lógico e quase inevitável em termos económicos desde que o projecto da «zona escudo» falhou e que a Inglaterra saiu da EFTA e entrou na CEE, ambos acontecimentos de começo dos anos 70, anteriores ao 25 de Abril. Se Marcelo Caetano se ficou pela negociação de um tratado de comércio com a CEE sem pedir a adesão em 1972, foi pelo simples motivo que não o podia fazer na altura, devido ao tipo de regime, à pauta especial que vigorava com as colónias e à mentalidade da sociedade portuguesa de então, onde a integração europeia pouco peso tinha. Do mesmo modo, se o Portugal posterior ao 25 de Abril não pediu a adesão, foi porque ela estava fora de causa antes de se decidir a descolonização e o tipo de regime que se implantaria em Portugal.

${ }^{42}$ Séries Longas Para a Economia Portuguesa, Banco de Portugal, Lisboa, 1997. 
Depois do 25 de Novembro, o Governo de Pinheiro de Azevedo sentia-se provisório e ainda estava sobretudo preocupado com os problemas dos equilíbrio políticos internos e da consolidação dos frutos obtidos com o 25 de Novembro, pelo que evitava tomar medidas de fundo. Por esse motivo, a política de austeridade não foi adoptada no grau necessário e os contactos com a CEE, embora se aprofundassem, não chegaram a um pedido formal de adesão.

Foi necessária a formação do $1 .{ }^{\circ}$ Governo Constitucional de Mário Soares (a 12 de Julho de 1976) para que reunissem as condições políticas necessárias para pensar a sério na adesão.

Em 1976, porém, a eventual adesão portuguesa à CEE não era simples. Portugal pela sua diminuta dimensão seria facilmente absorvido pela CEE, mas a viragem para a democracia da Grécia e da Espanha tinha colocado este problema num contexto mais amplo, onde o que estava em causa era um vasto movimento de abertura e integração do Sul da Europa. Do ponto de vista da CEE, tratava-se de um problema importante, pois as economias pouco desenvolvidas destes três estados exigiam uma ajuda substancial e um período longo de integração plena, o que iria perturbar seriamente os equilíbrios existentes e provocava reacções negativas em vários sectores económicos e sociais. Certos países viam com fortes reservas esta hipótese, embora reconhecessem a sua vantagem de longo prazo.

Do ponto de vista de Portugal a aproximação gradual à CEE será o tema central das relações externas desde o 25 de Novembro, embora, como já referimos, só depois da formação do $1 .^{a}$ Governo Constitucional se tenham criado as condições políticas para pedir a adesão. Esta era essencial para resolver o problema de fundo da falta de um equilíbrio nos fluxos financeiros e económicos com o exterior e para modernizar a economia.

O 1. ${ }^{\circ}$ Governo Constitucional inicia as sondagens prévias para a adesão à CEE pouco depois da sua formação, contando sobretudo com a boa vontade da RFA (que se viria a revelar real) e da Inglaterra (onde surgiriam vários problemas). $\mathrm{O}$ assunto será amplamente discutido na CEE a partir de começos de 1977, dentro da perspectiva mais ampla do alargamento ao sul da Europa. Os pequenos países, como a Holanda e a Bélgica, tendiam a considerar que a comunidade se devia primeiro consolidar antes de pensar em novos alargamentos. Os problemas eram especialmente fortes no que dizia respeito à política agrícola comum, o que afectava sobretudo os países do Sul, como a França e a Itália. . Em última instância, o que decidiu o debate interno da CEE foi uma opção política de fundo: a integração desejada pelos três estados do sul era considerado como importante para permitir que neles se consolidassem as democracias com fracas tradições no século Xx, e era um passo essencial no «sonho europeu».

No seguimento destes contactos o Governo de Mário Soares anuncia em Fevereiro que o pedido de adesão portuguesa será apresentado a curto prazo, o que se concretiza a 28 de Março desse ano, com garantias prévias de um acolhimento favorável. Medeiros Ferreira era então o Ministro dos Negócios Estrangeiros. 
As negociações concretas tardam a começar, pois o Conselho de Ministros da CEE só elabora um parecer favorável em Maio de 1978, mais de um ano depois de apresentado o pedido. Há, no entanto uma condição importante que condicionaria fortemente todo o processo de adesão e que a diplomacia portuguesa não conseguiu evitar, por razões que ainda não foram devidamente estudadas: a CEE insistia em considerar os pedidos de Portugal e da Espanha em conjunto. Tal significava que, se os menos de $5 \%$ do PNB português em relação à CEE pouco pesavam, já o peso da economia peninsular era considerável, o que apontavam para negociações complexas e prolongadas.

Estas só arrancam no Luxemburgo em Outubro de 1978. Como seria de esperar, prolongam-se por muitos anos. Neste período, como muito bem refere o Ministro dos Negócios Estrangeiros Jaime Gama em 1983, a prioridade número um da política externa portuguesa é «a aceleração da fase final do processo de negociações para o ingresso nas Comunidades Europeias» "43. $O$ tratado de adesão foi assinado a 12 de Junho de 1985 (8 anos depois da apresentação pedido oficial), com concretização a partir de 1 de Janeiro de 1986.

\subsection{A obtenção de créditos externos}

Ao longo de todo este período é igualmente importante a necessidade de obter substanciais créditos externos para resolver os problemas de curto prazo da economia portuguesa.

A boa vontade americana depois do 25 de Novembro é aproveitada para começar as negociações do primeiro crédito realmente substancial (pensava-se em 1,5 bilhões de dólares) conseguido do outro lado do Atlântico desde o 25 de Abril. Uma delegação encabeçada pelo Ministro das Finanças Salgado Zenha visita Washington em Março de 1976 para iniciar as negociações, que se vão prolongar por muitos meses e envolver o FMI. Os créditos resultantes em fatias graduais começam a chegar a partir de 1977, no período mais agudo da crise financeira.

São igualmente adoptadas medidas importantes para rever a legislação sobre as relações financeiras com o exterior, como seja a aprovação de um novo código do investimento estrangeiro em Abril de 1976 (DL 238/76), onde é evidente a preocupação de atrair divisas. Estamos no período de activa fuga de capitais, legal e ilegal, que atinge valores muito substanciais à escala nacional. Em Setembro de 1976 será assinado um protocolo financeiro com a CEE, válido por 5 anos, onde se prevêem créditos de cerca de 200 milhões de ECUS. É um documento que se pode já considerar como uma medida de pré-adesão, facto que não deixa de ser mencionado pelo lado português.

43 Discurso de Jaime Gama a 23 de Junho de 1983, na apresentação do programa do Governo na Assembleia da República. Política Externa Portuguesa 1983-1985, MNE, Lisboa, p. 12. 


\subsection{Outras preocupações}

As relações externas de Portugal nesta $3 .^{a}$ fase passam por inúmeros outras vertentes, embora as já mencionadas sejam as prioritárias.

Há a preocupação de alicerçar em laços tão sólidos quanto possíveis as relações de Portugal com os novos países de expressão portuguesa. A situação é complicada neste campo pela guerra civil que não tarda a instalar-se em Angola e Moçambique. O Estado Português define no essencial uma política de não ingerência e de manutenção de relações tão normais quanto possível com os Governos que dominam as capitais e a maior parte do território. São criados e desenvolvidos os principais mecanismos de cooperação, tanto em termos culturais, como económicos e financeiros e formadas as instituições encarregadas de os gerir do lado português. $O$ grande problema neste campo é a penúria de recursos financeiros onde alicerçar uma sólida cooperação, muito em especial pelas graves dificuldades de cumprir os compromissos económicos que os novos estados revelam desde o primeiro momento. Isto faz com que em larga medida os quadros portugueses, melhor adaptados na maior parte dos casos às realidades dos novos países africanos, não sejam apoiados por uma estrutura e meios que permitiriam valorizar o seu trabalho.

Outra vertente importante é a regularização das negociações com os EUA, depois do período agitado do verão quente. Há no essencial dois assuntos prioritárias neste processo: as negociações dos mecanismos de apoio financeiro já mencionados e a renovação do acordo da base das Lajes, dentro de uma filosofia muito diferente do passado.

Ligado ao ponto anterior, regista-se uma reaproximação à NATO, de que o país se afastou voluntariamente desde 1961 e por força das circunstâncias durante o período agitado anterior ao 25 de Novembro. A reaproximação é muito importante, pois só a NATO permitirá dar alguma coerência e lógica ao esforço de criar uma nova política de defesa, que passa nomeadamente pela ampla restruturação das Forças Armadas. Qualquer dos seus ramos tinha equipamento obsoleto em termos europeus e uma estrutura muito pouco adaptada às necessidades da NATO e ao regime democrático. Só o apoio da NATO e a renegociação das formas de participação na organização permitiriam obter as técnicas, meios e recursos para iniciar a ampla transição que, em certo sentido, só agora termina, passados 25 anos.

Outra preocupação de grande importância é a revisão das relações com a Espanha, que inicia a transição para a democracia. O processo português foi, como já referimos, importante para o curso seguido pela Espanha mas, a partir de 1977 a situação invertesse e será o país vizinho a exercer uma importante influência na fase final da transição nacional.

Há finalmente um conjunto de aspectos importantes na política externa deste período, embora sem a prioridade dos já mencionados: o problema de Timor, 
onde a população tinha de sofrer a ocupação da Indonésia depois da invasão; a normalização das relações com o Brasil, onde a revolução portuguesa foi acompanhada de forma negativa por importantes sectores económicos e culturais; a consolidação da abertura ao mundo, com a negociação de inúmeros mecanismos de cooperação com a Europa de Leste e o mundo Árabe; as preocupações com as comunidades e a difusão da língua e cultura portuguesa no exterior; a abertura nas relações com o Extremo Oriente, tanto em termos da China como dos «tigres» da zona.

\subsection{Uma perspectiva de longo prazo}

Em termos gerais a integração de Portugal na CEE deve ser entendida como a correcção de uma anomalia de fundo, no sentido de que as relações externas portuguesas tinham as Comunidades no seu centro desde o final dos anos 50, mas a adesão era impossível enquanto permanecessem os laços de ligação ao Império e enquanto o regime não fosse uma democracia pluralista, o que eram factos interligados.

Era a segunda grande viragem internacional de Portugal na época contemporânea, um movimento de fundo com amplas repercussões no futuro e que obrigava a rever tudo. A primeira viragem deu-se em 1807/1825, quando o Brasil se tornou independente (primeiro de um ponto de vista económico e depois político), colocando um fim efectivo no segundo império português. Gerou-se então um profundo sentimento de incerteza e pessimismo, acompanhado pela necessidade amplamente sentida de «regeneração» do país. Começou então um período longo de instabilidade política, onde o país se dividiu profundamente e andou à deriva por dezenas de anos (entre 1820 e 1850), marcados por revoluções, insurreições, levantamentos, guerras civis e intervenções externas permanentes. As convulsões políticas internas iniciadas em 1974 nada são comparadas com estas: reduzem-se a ano e meio de agitação e instabilidade, sem guerra civil e sem intervenção externa formal. Mesmo a chamada «transição pacífica» espanhola teve mais mortos políticos num mês qualquer que os registados em toda a «revolução» portuguesa.

É inevitável perguntar como é isto possível, tendo em conta que a mudança ensaiada é tão grande ou maior do que a de 1807/1825? Penso que as principais razões já foram referidas: o bom senso do povo português, apesar dos excessos verbais inerentes à época, e o facto dos factores de continuidade e regresso à tradição seram muito fortes, embora as aparências fossem em sentido contrário.

O conturbado ano e meio de agitação posterior ao 25 de Abril, a chamada «revolução portuguesa" deve ser lido com algum distanciamento como um preço relativamente benigno e moderado por um reajustamento na posição de Portugal no mundo, numa altura de globalização. Penso que os historiadores futuros o irão encarar como um pequeno episódio numa transição muito mais ampla, que 
ainda não acabou: a transição para as sociedades pós industriais do final do século xx. A democratização era um passo obrigatório dessa transição, mas simplesmente um passo.

No curto prazo e em termos da visão dos portugueses que viveram o processo, foi, contudo, algo único, que marcou as suas vidas. Uma espécie de período mágico, onde as regras do jogo social tradicionais deixam de funcionar e onde tudo parece possível, até o facto de um governo entrar em greve. Foi uma luta pela alma de Portugal, pela escolha de uma opção de fundo que era a óbvia, mas não a obrigatória. Nesse processo o elemento fundamental foi o interno. Os factores externos cumprem um papel subordinado e, dentro deles, o mais importante é a influência multifacetada da CEE e, em particular, da RFA.

Foi um processo onde se destacaram muitos nomes, de civis e militares. É quase obrigatório mencionar Melo Antunes, Vasco Lourenço, Spínola, Costa Gomes, Otelo Saraiva de Carvalho, Sá Carneiro, Freitas do Amaral, Adelino Amaro da Costa, Salgado Zenha e muitos mais. No entanto, penso que há um nome em especial que marca este processo, e que em larga medida se faz com ele porque 0 entende e o assume. Trata-se, como é evidente, do Dr. Mário Soares que em qualquer das três fases mencionadas acaba por ser o centro do pequeno grupo que define em primeiro lugar a política que acaba por vencer tanto em termos internos como externos. É ela que assegura o sucesso da transição portuguesa para a democracia pluralista e representativa europeia de finais do século $\mathrm{xx}$.

\section{BIBLIOGRAFÍA}

ANTUNES, José Freire - Os Americanos e Portugal, Lisboa, D. Quixote, 1986

Bruneau, Thomas - Politics and Nationhood: Post-Revolutinary Portugal, Nova York, Praeger, 1984.

CARRILHo, Maria - Forças Armadas e Mudança Social em Portugal no Século xx, Lisboa, 1985.

Cervelló, Joseph Sanchez - A Revolução Portuguesa, Assírio e Alvim, Lisboa, 1993.

CruzeIRo, Maria Manuela (entrevista) - Costa Gomes o último Marechal, Editorial Notícias, Lisboa, 1998.

GamA, Jaime - Política Externa Portuguesa 1983-1985, MNE, Lisboa, 1987.

— «A Adesão de Portugal às Comunidades Europeias», Política Internacional, n. ${ }^{\circ}$ 10, Inverno de 1994 1995, pp. 5-19.

Huntington, Samuel P. - The Third Wave: Democratisation in the late Twentieh Century, Norman, University of Oklahoma Press, 1991.

ISAACSON, Walter - Kissinger, Simon and Schuster, Nova York, 1992.

MAGALHÃES, José Calvet de - «Portugal e os EUA-Relações no Domínio da Defesa», Estratégia, n. ${ }^{\circ} 4$, Inverno de 1987/1988, pp. 31-42.

MAGONE, José - „A integração europeia e a construção da democracia portuguesa», José Magone, Actas do Colóquio Portugal e a Unificação Europeia, Penélope 18, Lisboa, 1998, pp. 123-167.

MAxweLL, Kenneth - The Making of Portuguese Democracy, Cambridge, Cambridge University Press, 1995.

McDonald, Scott B. - European Destiny, Atlantic Transformations, New Brunswick, Transaction Publishers, 1992.

Pereira, Bernardo Futscher - «Continuidade na Mudança. As Relações Entre Portugal e os EUA», Política Internacional, n. ${ }^{\circ} 2$, Junho de 1990, pp. 5-19.

Rocha, Alfredo Ramos - «Portugal e a Defesa Ocidental: Problemas Militares e Estratégicos», Proserpina n. ${ }^{\circ} 8$, Abril de 1989, Mérida, pp. 71-81. 
SOARES, Mário - Portugal Amordaçado, Lisboa, 1974.

- Democratização e Descolonização - Dez Meses no Governo Provisório, Lisboa, MNE, 1975.

TEIXEIRA, Nuno Severiano - «Portugal e a NATO: 1949-1989», Análise Social, ICSUL, Lisboa, n. ${ }^{\circ} 133$, 1995, pp. 803-819.

Telo, António José - Portugal e a NATO, Lisboa, Edições Cosmos, 1996.

- Do Tratado de Tordesilhas à Guerra Fria, Blumenau, FURB, 1996.

TORRE GómEZ, Hipólito de la - Portugal en el Exterior (1807-1974). Intereses y política internacionales, Madrid, UNED, 2006.

- El Portugal de Salazar, Madrid, Arco Libros, 1997.

- «Unidad e Dualismo Peninsular», em H. de la Torre (ed.), Portugal y España Contemporâneos, Madrid, Marcel Pons, 2000, pp. 11-35.

THEMIDO, João Hall - Dez anos de Washington, Dom Quixote, Lisboa, 1995. 